\title{
HYPOTHESES ON GLIDES AND MATRES LECTIONIS IN EARLIER EGYPTIAN ORTHOGRAPHIES
}

\author{
DANIEL A. WERNING
}

WITH THIS CONTRIBUTION, I would like to argue that, in future research on Earlier Egyptian morpho-syntax, we also need to focus on key issues of orthography. That is, we need to research individual orthographic standards of particular scribal "schools," of particular documents, and we should check, or at least make explicit, our presuppositions on the orthographic system. In this regard, a key issue is the relationship of written and underlying phonological and phonetic forms (e.g., what might be labeled the "Defective Spelling Hypothesis," the "Frozen Spelling Hypothesis," the "Pre-Coptic Syllable Structure Rules Hypothesis," including the "Zweisilbengesetz" and the "Consonantal Auslaut Hypothesis," the "Three Vowel Qualities Hypothesis," the "Pre-Coptic Vowel Length Rule Hypothesis," and so on). ${ }^{1}$

To exemplify the need for more discussion about these issues, I am going to present and argue for a set of hypotheses on Earlier Egyptian orthographies that - given the reader accepts it - has an impact on the identification of certain morpho-syntactic forms such as, for example, the Subjunctive $s \underline{d} m(=f)$, the Posterior $s \underline{d} m . w / y(=f)$ (alias Prospective), the Resultative $s \underline{d} m . k w / s \underline{d} m . t i / s \underline{d} m . w / \ldots$ (alias Pseudo-participle), the Passive $\operatorname{sd} m(. w)(=f)$, and the relation of the Passive Distributive Participle $s \underline{d} m . w$ and the Imperfective Relative Form $s \underline{d} m \cdot w / y(=f) .^{2}$

\section{PART I. THE CONCEPT OF MATER LECTIONIS IN EARLIER EGYPTIAN ORTHOGRAPHY; OR: WHY $s \underline{d} m \boldsymbol{w}$ MIGHT REPRESENT A SUBJUNCTIVE * $s \breve{c} m \dot{\boldsymbol{a}}$}

Normally, occurrences of the glides ("semi-consonants" or "semi-vowels") $w$ (, , in $\odot$, and others) and $i\left(h\right.$, in $\downarrow$ and others), $y\left(\ell\{)\right.$, or $\ddot{i}(\because \text { or } 1)^{3}$ have been taken as evidence that the respective forms actually contained a corresponding consonantal phoneme $/ \mathrm{w} /$ or $/ \mathrm{j} /{ }^{4}$ This is, of course, reasonable if the spelling exhibits the glides more often than not. But in some influential works on Earlier Egyptian grammar and vocalization, the same thing is also assumed in those cases in which the glides were spelled out in only a very limited number of occurrences (if any). Some scholars assume that the consonants were present in the spoken form but not in the written form ("Defective Spelling Hypothesis" proper); others assume that the consonants were present at some earlier time but no longer at the time of the creation of the relevant document ("Traditional Spelling Hypothesis"). A third explanation is that the consonants are somehow present conceptually but are not spoken phonetically ("Phonetic Phonology Hypothesis"). Anyhow, in

1 This contribution tries to work on the basis of the Three Vowel Qualities Hypothesis and the Pre-Coptic Syllable Structure Rules Hypothesis, except that it allows for open syllables at the end of the word (-CV), and on the kernel idea of the PreCoptic Vowel Length Rule Hypothesis as regards the fate of stressed vowels in open and closed syllables. It is hesitant about the validity of the Zweisilbengesetz in inflected forms. It substitutes the Defective Spelling Hypothesis for a Fluctuating Glide Hypothesis (see Hypothesis no. 5, Part IV, below). It also acknowledges Frozen Spellings to a certain extent.

2 Throughout this article phonemes are marked by /.../, approximate phonetic renderings by [...], and single graphemes by $\langle\ldots\rangle$. A "V" stands for an unknown vowel. A list of abbreviations not in the Bibliography is appended at the end of this article.

3 Traditionally, the transliterations of both $\|$ and $\|$ equal the transliteration of $\lfloor\downarrow$ rather than that of $\{$ (Werning 2007). Brose $(2014, \S \S 9.6,18)$ states that, in certain Middle Egyptian documentary texts, a rather large $\|$ always equals $\{\nmid$ while $\backslash$ doesn't.

$4 \quad$ Throughout this paper, the phonological interpretations of $i$ are based on the assumption that the grapheme $\langle i\rangle$ primarily refers to a glide $(/ \mathrm{j} /)$. The arguments, however, also work if one subscribes to the assumption that it primarily refers to a glottal stop /P/ (the only exception being the semi-vocalic nature of the ult.-inf. radical of verbal roots: see Part IV, below). 
many past publications from and in the following of Sethe $(1923, \S 4)$, Fecht, Edel, and Osing - and this is the crucial point - even very occasional spellings of forms with glides have been taken as evidence that there was a full consonant in the form. The reconstruction of such a "consonantal glide" has certain consequences for the reconstruction of the syllable structure of the word. In particular, according to the Syllable Structure Rules Hypothesis, there has to be at least one vowel next to it. $^{5}$

In this tradition, for example, the $t w$-passive of certain suffix conjugation tenses followed by a monoconsonantal personal pronoun is reconstructed as follows:

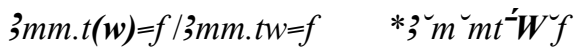

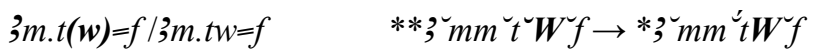

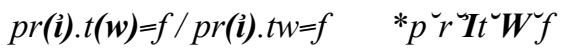

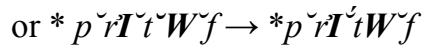

\begin{tabular}{|c|c|c|c|}
\hline ;h(.i) “spirit" & 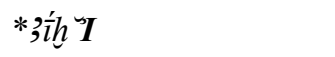 & */'ri:xVJ/ & $>>^{\mathrm{A} 2} 12 \sim{ }^{\mathrm{B}} \mathrm{ln} ;{ }^{6}$ \\
\hline ,hh(.ỉ).w / ;h(.i.w) "spirits" & 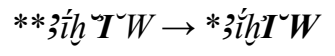 & */'RixJVW/; & \\
\hline it(.ì) "father" & *iát $\mathbf{I}$ & */'ja:tVJ/ & $>{ }^{\mathrm{SB}} \mathbf{\epsilon i \omega T}$ \\
\hline it(.i).w / it(.i.w) "fathers" & 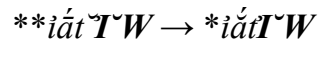 & */'jatJVW/ & $>{ }^{\mathrm{S}}$ еіоте ${ }^{\circ}$ \\
\hline hrw(.w) "day" & 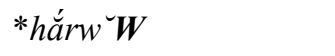 & */'harwVW/ & $>\mathrm{SBAA}^{\mathrm{SBOO} \gamma} \sim{ }^{\mathrm{AA} 2}$ гоOү⿷ \\
\hline$h r(\boldsymbol{w}) \cdot w(\cdot \boldsymbol{w})$ "days" & $* h a r \boldsymbol{W}^{\prime} w^{-} \boldsymbol{W}$ & */har'WV:wV & $>{ }^{\mathrm{AA} 2} 2 \mathrm{PEY}$ \\
\hline
\end{tabular}

\begin{tabular}{|c|c|c|c|}
\hline ;h(.ỉ).w / ,hh(.i.w) "spirits" & 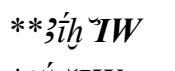 & */'ri:xVJW/; & \\
\hline 穴. & *iắt $\mathbf{I W}$ & */'ja:tVJW/ > (?) & $>{ }^{\mathrm{S}}$ eIOTE; \\
\hline$h r(\boldsymbol{w}) \cdot w(\cdot \boldsymbol{w})$ "days" & $* h a r \boldsymbol{W}^{\prime} w w$ & */har'WVww/ & $>{ }^{\mathrm{AA} 2} 2 \mathrm{PE} Y$ \\
\hline
\end{tabular}

And the plural of, for example, the following nouns is reconstructed as

or, if we take Wolfgang Schenkel's revision of Earlier Egyptian syllable structures $(1983 b, 198)$ into account, we may reconstruct:

Within the framework of the traditional set of hypotheses on Earlier Egyptian syllable structures, there is a limited number of other options. It usually follows that, besides $/ \mathrm{wV} /, / \mathrm{Vw} /, \mathrm{jV} /$, and $/ \mathrm{Vj} /$, rather substantial phonological clusters like /Vjw/, /jVw/, and /V:wV/ were allegedly often left unwritten in Earlier Egyptian orthographies. In particular, cases of alleged omission of intervocalic glides, i.e. / $\mathrm{VwV} /$ and $/ \mathrm{VjV} /$, have always been very suspicious to me. This leads me to my first axiomatic pre-assumption:

\section{Pre-assumption 1 (“Intervocalic Glide Axiom")}

Intervocalic glides $(/ \mathrm{VwV} /$ and $/ \mathrm{VjV} /)$ usually appear spelled out as $w$ and $i$ or $y$, respectively.

As an alternative to taking any even sparse occurrence of a glide in a specific word form as a proof for the existence of a consonant, it is also possible to assume that the phonograms $\langle w\rangle,\langle i\rangle,\langle t i\rangle$ and probably $\langle y\rangle$ can hint at a vowel ("Mater Lectionis Hypothesis"). This has been assumed by different scholars from time to time-most explicitly Thacker 1954 (7-31) — but I am probably not mistaken in saying that later

5 For the traditional hypotheses, see, e.g., Schenkel 1990, Chapter 2; Peust 1999.

6 Cf. Schenkel 1983b, 176; revision in Schenkel 2009b, 270-73.

7 Cf., e.g., Edel 1955-64, §§ 335, 339.

8 Cf., e.g., Satzinger 1999a, 373. 
mainstream discussion has not yet explored this hypothesis in depth, surely not in its full consequences. ${ }^{9}$ On the other hand, there is barely any scholar who has not at least taken into account the possibility that $w$ and/or $i$ might hint at a vowel, either explicitly in a comment or implicitly in one or another analysis. ${ }^{10}$ There are, however, some recent studies that have come independently to the conclusion that there are matres lectionis in Earlier Egyptian orthographies. ${ }^{11}$

When I say that the matres lectionis "hint at a vowel" rather than "represent a vowel," I want to be cautious not to easily equate $\langle w\rangle$ with $/ \mathrm{u} /$ or $/ \mathrm{u}: /$ and $\langle i\rangle,\langle y\rangle,\langle i\rangle$ with $/ \mathrm{i} /$ or $/ \mathrm{i}$ /. Indeed, it seems that, for example, the "glide" $\{$ might hint at the existence of various different vowels in the OK, or even at the existence of any vowel, no matter what quality or quantity. ${ }^{12}$ This also implies that the notion of "mater lectionis," as I use it, is a broader one: a reading aid that hints at either a specific vowel or generally at a non-specified vowel.

Instead of tracing the arguments that led the respective scholars to conclude that matres lectionis exist in Earlier Egyptian, I would like to explore specific possible examples and more general consequences. I start with a first fundamental working hypothesis:

\section{Hypothesis 1 ("Mater Lectionis Hypothesis")}

If a certain word or morpheme is spelled much more often without a specific glide at a certain position than with the glide, the occasionally written glide hints at a vowel (yet to be determined) which occupies a vocalic slot in the syllable structure (rather than at a respective consonant that occupies a consonantal slot).

This hypothesis surely needs some refinement, for example as regards the text corpus and as to how much "much more" actually is. But the point that I want to make is to reject the traditional hypothesis that even rare occurrences of glides testify to the existence of a consonant (which needs to be assigned a consonantal slot in the assumed possible syllable structures).

Operating with Hypothesis 1, the following are probably cases that are occasionally spelled with matres lectionis.

Table 1: Cases of possible matres lectionis in Earlier Egyptian orthographies

\begin{tabular}{|c|c|c|c|c|}
\hline & OK SPELLINGS & MK SPELLINGS & $\begin{array}{l}\text { RECONSTRUCTION } \\
\text { HYPOTHESIS }\end{array}$ & $\begin{array}{l}\text { SEE } \\
\text { Note }\end{array}$ \\
\hline $\begin{array}{l}\text { Resultative ending, } \\
1 \mathrm{SG}\end{array}$ & $\begin{array}{l}\text { usually } \sqcup ; \\
\text { relig. texts also } \square \text {; } \\
\text { once } \square / n\end{array}$ & 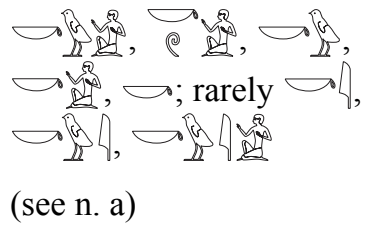 & $* /(\mathrm{a}:) \mathrm{ku} /$ & b) \\
\hline
\end{tabular}

9 But see now Allen 2013. For a list of consequences that result from a vocalic reconstruction of the nisbe morpheme, see Schultheiß 2014, Chap. 8.3 "Zusammenfassung und Schlussbetrachtungen."

10 E.g., Gardiner 1957, $\S 20$ ( $i$ and $w$ as "semi-vowels"); Loprieno 1995, 62-63 (noun endings); Kammerzell 1998, 113 ( $t i l t w-$ Passive); Malaise \& Winand 1999, § 24 ( $i$ for */i/, $w$ for */u/); Allen 2000/2010, $\$ 2.4$ ( $i$ for */i/, $w$ for */u/), § 17.2 (Resultative endings); now Allen 2013, 38 and 53 ( $i$ "to signal a vocalic desinence"), 43 and 53 ( $w$ for */u/, $w$ "also represents a final vowel"); Vernus 2000, 185 (Resultative endings); Grandet \& Mathieu 2003, 11.4 ( $i / i$ for */i/, $w$ for */u/); Schenkel 2005c/2012a, Chap. 2.1 ( $i$ possibly vocalic ending); ; Stauder 2014a, 12-13 (ti/tw-Passive and Resultative endings).

11 Schenkel 2009b, 269-74; Werning 2011, I, §§ 56-57, 60, 65, 81; Schultheiß 2014.

12 Thacker 1954, 31; Schenkel 2009b, 273-74 (long vowels only?); Werning 2011, I, § 57. 


\begin{tabular}{|c|c|c|c|c|}
\hline & OK SPELLINGS & MK SPELLINGS & $\begin{array}{l}\text { RECONSTRUCTION } \\
\text { HYPOTHESIS }\end{array}$ & $\begin{array}{l}\text { SEE } \\
\text { NOTE }\end{array}$ \\
\hline $\begin{array}{l}\text { Resultative ending, } \\
\text { 2SG.M }\end{array}$ & \multirow{5}{*}{$\begin{array}{l}\text { usually } \circ ; \\
\text { rarely }], 72, \triangle 7 h, \triangle\}\end{array}$} & \multirow{3}{*}{ 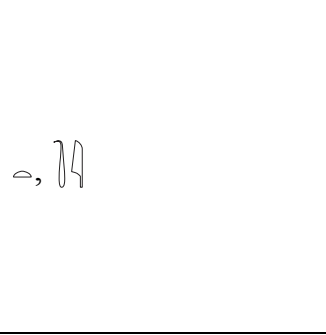 } & $* /($ a: $) \mathrm{ta} /$ & \multirow[t]{5}{*}{ c) } \\
\hline $\begin{array}{l}\text { Resultative ending, } \\
2 \text { SG.F }\end{array}$ & & & $* /($ 'a:)ti/ & \\
\hline $\begin{array}{l}\text { Resultative ending, } \\
\text { 3SG.F }\end{array}$ & & & $* /(' \mathrm{a}:) \mathrm{t} \mathbf{V} /$ & \\
\hline Resultative ending, & & rarely 74; & see 3SG.F & \\
\hline 3PL.F & & usually $\rightarrow$ 3PL.M & see 3PL.M & \\
\hline $\begin{array}{l}\text { Resultative ending, } \\
\text { 3SG.M }\end{array}$ & $\begin{array}{l}\text { usually ø; also } \downarrow \text {; } \\
\text { more rarely }\end{array}$ & $\begin{array}{l}\text { usually } ø ; \\
\text { more rarely } b,\end{array}$ & $* / \mathbf{a} /$ & d) \\
\hline $\begin{array}{l}\text { Resultative ending, } \\
\text { 3PL.M }\end{array}$ & $\begin{array}{l}\text { usually } ø \text {; also } 4 ; \\
\text { more rarely } 5,44,244, \\
\text { once } 48\end{array}$ & $\begin{array}{l}\text { usually ø; } \\
\text { more rarely } h \text {, }\end{array}$ & $* / \mathbf{u} /$ & e) \\
\hline $\begin{array}{l}\text { Resultative ending, } \\
1 \mathrm{PL}\end{array}$ & $\begin{array}{l}\text { probably once } 8 \\
\text { prarely attested); }\end{array}$ & $\begin{array}{l}\text {, f }, ~ \\
\text { (plus } \Vdash \| \text {, see n. f) }\end{array}$ & $\begin{array}{l}\text { */u:nu/, } \\
\text { after */'a/: } \\
\text { ['awnu] }\end{array}$ & \multirow[t]{2}{*}{ g) } \\
\hline $\begin{array}{l}\text { Resultative ending, } \\
\text { 1PL (secondarily) }\end{array}$ & & 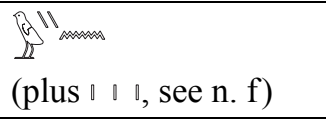 & */('a:)wi:n/ & \\
\hline $\begin{array}{l}\text { Resultative ending, } \\
\text { 2PL }\end{array}$ & ID & 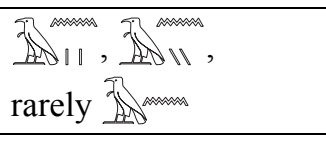 & */('a:)tu:ni:/ & h) \\
\hline$t$-passive morpheme & $\begin{array}{l}\text { usually } \triangle ; \\
\text { relig. texts also } 74,\end{array}$ & 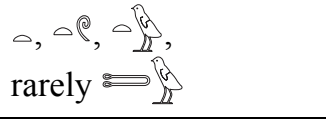 & $* / \mathrm{t} \mathbf{V} /$ & i) \\
\hline $\begin{array}{l}\text { Nominal forms M.SG } \\
\text { (allegedly) with final } \\
\text { weak consonant }\end{array}$ & $\begin{array}{l}\text { usually } ø ; \\
\text { very rarely }\{, \sqrt{n}\end{array}$ & $\varnothing$ & $\begin{array}{l}* / \mathbf{V} / \\
(* / \mathrm{u} /, * / \mathrm{i} /, * / \mathrm{a} / ?)\end{array}$ & j) \\
\hline $\begin{array}{l}\text { Nominal plural mor- } \\
\text { pheme, M }\end{array}$ & or $\_$ & 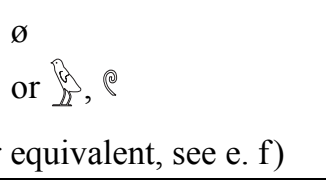 & $\begin{array}{l}* / \mathbf{u}: /, \\
\text { after vowel: } *[\mathrm{w}]\end{array}$ & k) \\
\hline $\begin{array}{l}\text { Nominal plural end- } \\
\text { ing, F }\end{array}$ & ○ & 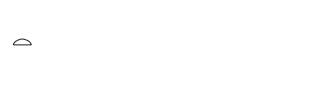 & $\begin{array}{l}* / \mathrm{V}: \mathrm{t} / \text { (vowel } \\
\text { lengthening) }\end{array}$ & 1) \\
\hline & 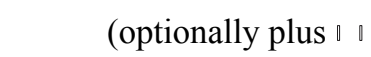 & equivalent, see n. f) & & \\
\hline $\begin{array}{l}\text { Suffix pronoun, 1SG } \\
(\text { trad. }=i)\end{array}$ & $\begin{array}{l}\text { usually } ø ; \\
\text { relig. texts often }\{\end{array}$ & 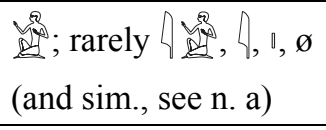 & $\begin{array}{l}* / \mathbf{i}: /, \\
\text { after vowel: } *[j]\end{array}$ & m) \\
\hline
\end{tabular}




\begin{tabular}{|c|c|c|c|c|}
\hline & OK SPELLINGS & MK SPELLINGS & $\begin{array}{l}\text { RECONSTRUCTION } \\
\text { HYPOTHESIS }\end{array}$ & $\begin{array}{l}\text { SEE } \\
\text { Note }\end{array}$ \\
\hline $\begin{array}{l}\text { Enclitic personal } \\
\text { pronoun, 1SG (trad. } \\
w i)\end{array}$ & 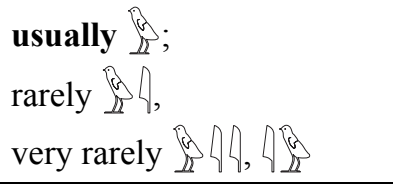 & 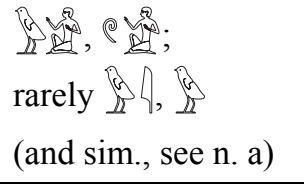 & $\begin{array}{l}* / \mathrm{w} \mathbf{V} / \\
(* / \mathrm{wu} / \text { or } * / \mathrm{wa} / ?)\end{array}$ & n) \\
\hline Nisbe ending, M.SG & $\begin{array}{l}\text { usually } \varnothing, \text { also } \$ ; \\
\text { rarely }\{4 .\end{array}$ & $\varnothing, \llbracket, \lll ;$ rarely \{\} & $* / \mathbf{i}: /$ & o) \\
\hline Nisbe ending, M.PL & 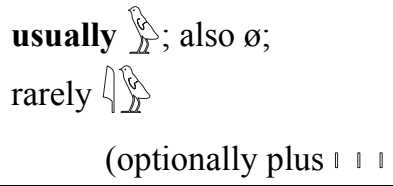 & $\begin{array}{l}\text { n, }, \text {; also ø } \\
\text { equivalent, see } n . f \text { ) }\end{array}$ & $*[\mathbf{i}: w](\sim * / \mathbf{i}: u: /)$ & \\
\hline Nisbe ending, F(SG/PL) & $\begin{array}{l}\text { usually } \odot ; \\
\text { rarely } h \subset,(h\} \odot ?) \\
\quad(\text { in PL contexts optior }\end{array}$ & lly plus $₫ \|$, see n. f) & $* / \mathbf{i}: \mathbf{t} /$ & \\
\hline $\begin{array}{l}\text { Nisbe ending, M.SG, } \\
\text { nouns } u l t .-t\end{array}$ & $\begin{array}{l}\text { usually } \triangle \text {, also } 7 h \text { or }] \text {; } \\
\text { rarely } \triangle\}, \triangle 4 h\end{array}$ & $\odot, \triangle \|$ & $* / \mathbf{t i}: /$ & \\
\hline $\begin{array}{l}\text { Nisbe ending, M.PL, } \\
\text { nouns } u l t .-t\end{array}$ & 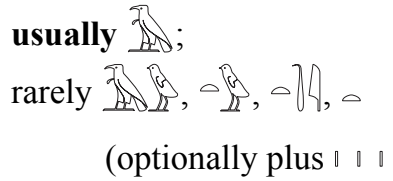 & 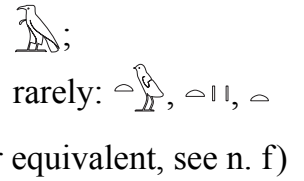 & $*[$ ti:w $](\sim /$ ti:u: $/)$ & \\
\hline $\begin{array}{l}\text { Nisbe ending, } \\
\text { F(SG/PL), nouns ult. }-t\end{array}$ & (in PL contexts option & lly plus $₫ \|$, see n. f) & $* / \mathrm{ti}: \mathrm{t} /$ & \\
\hline Particle $i w$ & $\begin{array}{l}48 \text {, before suffix pronoun } \\
\text { also } 4 \text {; relig. texts rarely } \\
\text { S46, } 4046 \text { s }\end{array}$ & $4 B, 40$ & $\begin{array}{l}* / \mathrm{PV}: / \text { or } * / \mathbf{V}: / \\
(* / \text { } \mathbf{u}: / \text { ?, before } \\
\text { mono-cons. suffix } \\
\text { pronoun: / } \mathbf{P u} . . / \text { ? })\end{array}$ & p) \\
\hline
\end{tabular}

\section{Table notes}

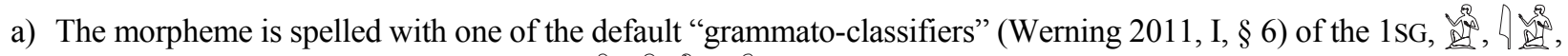
or 1 , or with a "semantic classifier," e.g. a grammatical morpheme as $1 \mathrm{SG}$ in, e.g., morpheme */i:/ as in $(=(i)$, trad. transliterated as “=i"). It is now generally accepted that the $\downarrow$ in MK spellings in

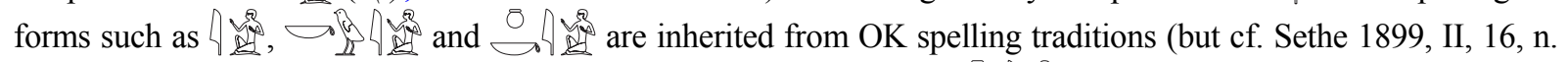
1). The classifiers are not a hint to a specific phoneme; cf. the spelling 80 迎 for *ianắk> dNok.

b) Spellings: Edel 1955-64, §§ 572-73; Gardiner 1957, § 309; Sethe 1899, II, §§ 34-35. Semitic equivalent as */ku:/ (Thacker 1954, 98); as */ku/ (Satzinger to appear). Egyptian reconstructions: as */ku:/ [ */kwV/(?)] (Thacker 1954, 125-26); as */ki/>*/ku/ (Reintges 1994, 214-15; Reintges 1997, 270); as */'a:ku/ (Loprieno 1995, 36), as */'aku/ (Allen 2000/2010, § 17.2), as */ku/ (Satzinger 1999b, 29; Satzinger 2007, 494; Vernus 2000, 185; Allen 2013, 67), */'a:ku/, */ku/ (Satzinger to appear [Stative vs. Perfect]), as */('a:)ku(:)/ (Schenkel 2009b, 273). For earlier approaches with consonantal ending, cf. Kammerzell 1991; Schenkel 1994a, 170; Loprieno $1995,76$. 
c) Spellings: Edel 1955-64, §§ 572-73; Gardiner 1957, § 309; Sethe 1899, II, §§ 23-33, 49-50. Semitic equivalent as 2SG.M */ta:/, 2SG.F */ti:/, 3SG.F */at/, 3PL.F */a:/ (Thacker 1954, 98); as 2SG.M */ta/, 2SG.F */ti/, 3SG.F */at/ (Satzinger to appear). Egyptian reconstructions: as 2SG.M */ta/, 2SG.F */ti/, 3SG.F*/tV/, 3PL.F */a:/ */tV/ (Thacker 1954, 121-24); as */ta/ */ti/ (Satzinger 1999b, 29; Satzinger 2007, 496); as */tV/ (Vernus 2000, 185); as 2sG.M */('a)ta/, 2SG.F */('a)ti/, 3SG.F */('a)ta/ (Allen 2000/2010, § 17.2); as 2SG.M */ta/ or */tu/, 2sG.F probably */ti/, $3 \mathrm{SG} . \mathrm{F} * / \mathrm{tV} /$, 3PL.F probably $=3 \mathrm{SG} . \mathrm{F}$ (Allen 2013, 67). For earlier approaches and the possibility of two paradigms, cf. Kammerzell 1991; Schenkel 1994a, 170.

d) Spellings: Edel 1955-64, §§572-73; Gardiner 1957, §309; Sethe 1899.II, §§15-18. Semitic equivalent as */a/ (Thacker 1954, 98); as */a/ or ø (Satzinger to appear). Egyptian reconstructions: as */V/ > *[ə] (Thacker 1954, 121); as */u/ (Vernus 2000, 185); as*/a/ (Allen 2000/2010, § 17.2); as */u/ or */a/ (Allen 2013, 67). For earlier approaches, cf. Kammerzell 1991; Schenkel 1994a, 170 [*/aw/ */ju:/, */aw/ */ji/].

e) Spellings: Edel 1955-64, §§ 572, 574; Gardiner 1957, § 309; Sethe 1899, II, §§ 44-46. Semitic equivalent as */u:/ (Thacker 1954, 98); Akkadian */u/ (Vernus 2000, 185). Egyptian reconstructions: as */u:/ (Thacker 1954, 122); as */u/ (Allen 2000/2010, § 17.2; Vernus 2000, 185); as probably */u?u/ >*/u/ (Allen 2013, 67). For an earlier approach, cf. Schenkel (1994a, 170 [*/'awu/ > */'aju/, */'awwi/ > */'ajji/]).

f) Plural morphemes are optionally spelled with one of the default "grammato-classifiers" (Werning 2011, I, § 6) for PL such as $₫ \| 1,111$, or $\circ \circ$, or, in certain cases, with a tripling of a sign or sign group.

g) Spellings: Edel 1955-64, $\S 572,574$ (with a comment on the possibly secondary character of $w \sim n$ ); Gardiner 1957, § 309; Sethe 1899, II, § 53. Semitic equivalent as */nu:/ (Thacker 1954, 98); Akkadian */nu/ (Vernus 2000, 185). Egyptian reconstructions: as */..nu:/(?) (Thacker 1954, 126-27); as */'anu/ (Allen 2000/2010, § 17.2; Allen 2013, 67); secondary form as */wVn/ (Vernus 2000, 185).

h) Spellings: Edel 1955-64, §§ 572, 574; Gardiner 1957, § 309; Sethe 1899, II, § 51. Semitic equivalent as 2PL.M */tunu:/, 2PL.M */tina:/ (Thacker 1954, 98); Akkadian 2PL.M */tunu/, 2PL.M */tina/ (Vernus 2000, 185). Egyptian reconstructions: as */tun/ or */tin(i?)/(?) (Thacker 1954, 124); as */'tawni/ (Schenkel 1994a, 170); as */'tu:nV/ (Satzinger 1999b, 29; Satzinger 2007, 496); as */tu:n/ (Vernus 2000, 185); as 2PL.M */('a)tunu/, 2PL.M */('a)tina/ (Allen 2000/2010, § 17.2; Allen 2013, 67).

i) OK spellings: Edel 1955-64, § 177; Kammerzell 1998, 112. Egyptian reconstructions: as */tV/ $>*$ [to] or the like (Thacker 1954, 315); as */ti/ >*/tu/ (Reintges 1997, 270); as */tV/ (Kammerzell 1998, 113); as probably*/tu/ (Allen 2013, 38); as */t(V)/ (Stauder 2014a:12).

j) This refers to nouns that are attested with final $i$ or $w$ in very rare cases (or even only once) or to nouns of the type Earlier Egyptian *(...)KK $\rightarrow$ Copt. ( ..)K $\boldsymbol{\omega}(\mathrm{K}) /(\ldots) \operatorname{Ko\gamma }(\mathrm{K}) /(\ldots) \mathrm{K} \mathbf{u}(\mathrm{K}) /(\ldots) \mathrm{Kr}(\mathrm{K})$ : Schenkel 2009b, § 3; Werning 2011, I, §§ 65a-b; cf. also Schenkel 1983, 202-204; Loprieno 1995, 36 and 62-63.

k) Spellings: Edel 1955-64, §§ 269-78; Gardiner 1957, §§ 72-74. Egyptian reconstructions: as */u:/ (Vycichl 1955, 264; Lambdin 1958, 183; Werning 2011, I, §§ 65a-b); as */wu/ (Vergote 1969); as **[u] $+[\mathrm{u}]>*[\mathrm{u}:]>*[\mathrm{w}]$ (Schenkel 1983, § 8, with a detailed discussion; cf. also Allen 2013, 61; Schenkel actually uses [u] instead of [w] as I should have in many cases in this very contribution; cf. also Barber 2013, $1 \mathrm{n}$. 2). For traditional reconstructions as $* / \mathrm{Vw} /$, cf. e.g. Vergote 1969, 77-79, Satzinger 1999a. I assume that some of the spellings with represent */Vw/-collectives morphologically rather than "true" plurals; cf. Werning 2011, I, §§ 65a-b.

1) Cf. Schenkel 1983, 208-209. I assume that spellings with (and $\mathrm{h}^{\circ}$ ) generally represent $* / w \mathrm{wt} /$-collectives morphologically (for $\mathrm{h}^{\circ} * / \mathrm{wVt} />$ A $\odot * / \mathrm{jVt} /$, cf. Schenkel 2012a, 105-106 and Part III below); cf. Werning 2011, I, $\S \S 17,20$.

m) Spellings: Edel 1955-64, §§ 159-60; Gardiner 1957, § 34. Egyptian reconstructions: */i/ (Erman 1894, § 140; Allen 2000/2010, § 5.3; Allen 2013, 66); as */i:/ after consonant, */jV/ after vowel (Thacker 1954, 21-23); as */i:/ 
(Vycichl 1955, 265); */aj/ (Loprieno 1995, 63-64). Note that the classifier itself does not hint at the phonological quality of the morpheme (cf. n. a, above).

n) Spellings: Edel 1955-64, §§ 166-67; Gardiner 1957, § 43. Egyptian reconstructions: */wV/, perhaps */wa/ (Allen $2013,68)$. A vocalization $* / w i /$ is unlikely since we never observe the assimilation effect $* / \mathrm{Vwi} />* / \mathrm{Vji} /$ as observed in other cases (cf. Part III, Hypothesis 4, below).

o) Werning 2011, I, 56 (M.SG *[i:], M.PL *[i(:)u], F.SG *[i(:)t], F.PL *[i:t]), see the references Werning 2011, I, 140 n. 145, 141 n. 149; additions: Schenkel 2008, 273 [M.SG */i:/, F.SG */it/], Schenkel 2009b, 270-71; Allen 2013, 74 [M.SG $* / \mathrm{i} /$, M.PL $* / \mathrm{iu} /$, M.DU $* /$ iua/ $\rightarrow * /$ iwa/, F.SG $* /$ iat/ $\sim * /$ it/, F.PL $* /$ iuat/ $>* /$ iwat/, F.DU $* /$ iata/ $>* /$ ita/]; Schultheiß 2014: Tables 6.1-6.2, 7.1, 7.3-7.4, 7.7 (spellings OK), Table 8.2 [status absolutus: M.SG */i:/, M.PL */i:w/, M.DU */i:wa:/], Table 8.1 [F.SG */i:t/, F.PL “*ût”, F.DU */i:ta:/].

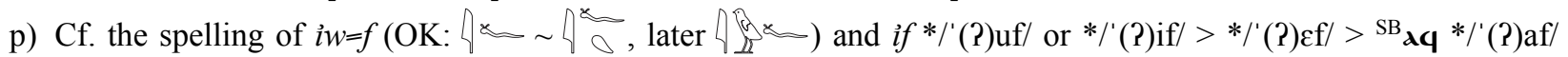

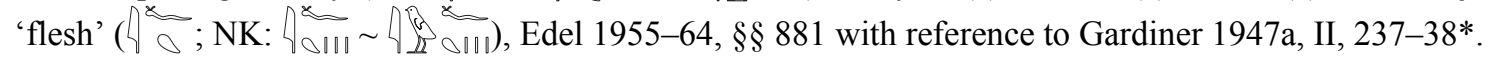

If we accept these reconstructions, we would conclude that in certain endings(!) the following relations exist:

Table 2: Spellings of vocalic and glide endings in Earlier Egyptian orthographies

\begin{tabular}{|c|c|c|c|c|}
\hline ENDING & & OK SPELLING & MK SPELLING & NOTES \\
\hline$/ \mathrm{w} /$ & e.g., Plural morpheme after vowels & $\sqrt{2},(\varnothing)$ & $\mathbb{e}, \sqrt{n},(\varnothing)$ & \\
\hline$/ \mathrm{tVw} /$ & e.g., Nisbe & 2N, ( D & $(-\sqrt{2})$ & \\
\hline /u:/ & Plural morpheme & $\varnothing, \beta$ & $\varnothing, \mathbb{C}, \AA$ & \\
\hline$/ \mathbf{u} /$ & Resultative ending 3PL.M & $\varnothing$, & $\varnothing, \mathbb{C}, \mathbb{R}$ & \\
\hline /tu:/ & inside Resultative ending 2PL(?) & $\therefore, 12$ & $\circ, 12$ & \\
\hline$/ \mathrm{tu} /$ & (no example; passive morpheme?) & & & \\
\hline$/ \mathrm{a}: /$ & (no example) & & & \\
\hline$/ \mathbf{a} /$ & Resultative ending 3SG.M & & $\varnothing, \mathbb{C}, \mathbb{R}$ & \\
\hline /ta:/ & inside personal pronoun $3 \mathrm{SG}$ & $\triangle,(], \circ)$ & & a) \\
\hline$/ \mathrm{ta} /$ & Resultative ending 2SG.M & $\therefore, 7,74, \triangle 71,-0$ & $\triangle$, & \\
\hline$/ \mathrm{j} /$ & $\begin{array}{l}\text { e.g., Nisbe morpheme after vowels, } \\
\text { suffix pronoun } 1 \mathrm{SG} \text { after vowels }\end{array}$ & {$[\hat{A},(\varnothing)]$} & {$[\{, \not\},, \Perp, \cdots,(\varnothing)]$} & \\
\hline$/ \mathrm{tVj} /$ & (no example) & & & \\
\hline$/ \mathbf{i}: /$ & $\begin{array}{l}\text { Nisbe morpheme (after consonant), } \\
\text { (Resultative ending 2PL?) }\end{array}$ & 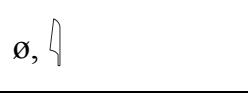 & $\varnothing, \|, \cdots,(A 4)$ & \\
\hline /i/ & (no example) & & & \\
\hline$/ \mathrm{ti}: /$ & Nisbe M.SG from nouns $u l t .-t$ & $\circ]$, & $\triangle \|, \triangle$ & \\
\hline$/ \mathrm{ti} /$ & Resultative ending 2SG.F & $-7,74,-74,-0$ & $=, \sqrt{4}$ & \\
\hline \multicolumn{4}{|c|}{ UNCLEAR } & \\
\hline$/ \mathrm{tV} /$ & Resultative ending 3SG.F & $,, \triangle 19, \infty$ & $\triangle, 21$ & \\
\hline$/ \mathrm{t} \mathbf{V} /$ & Passive morpheme & $\infty$, & $\triangle, \triangle e, \circ$ & \\
\hline$/ \mathrm{wV} /$ & Enclitic personal pronoun $1 \mathrm{SG}$ & 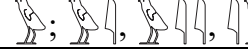 & 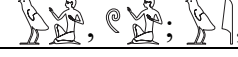 & \\
\hline
\end{tabular}

\section{Table notes}

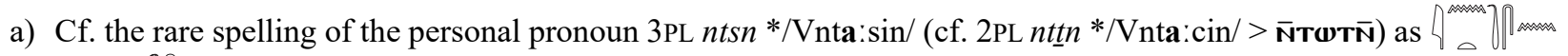
and $\sin x \| \int_{\max x}$ in the OK (Edel 1955-64, § 41).

Or, organized the other way around: 
Table 3: Possible interpretations of word-final or morpheme-final "glide" graphemes in Earlier Egyptian orthographies

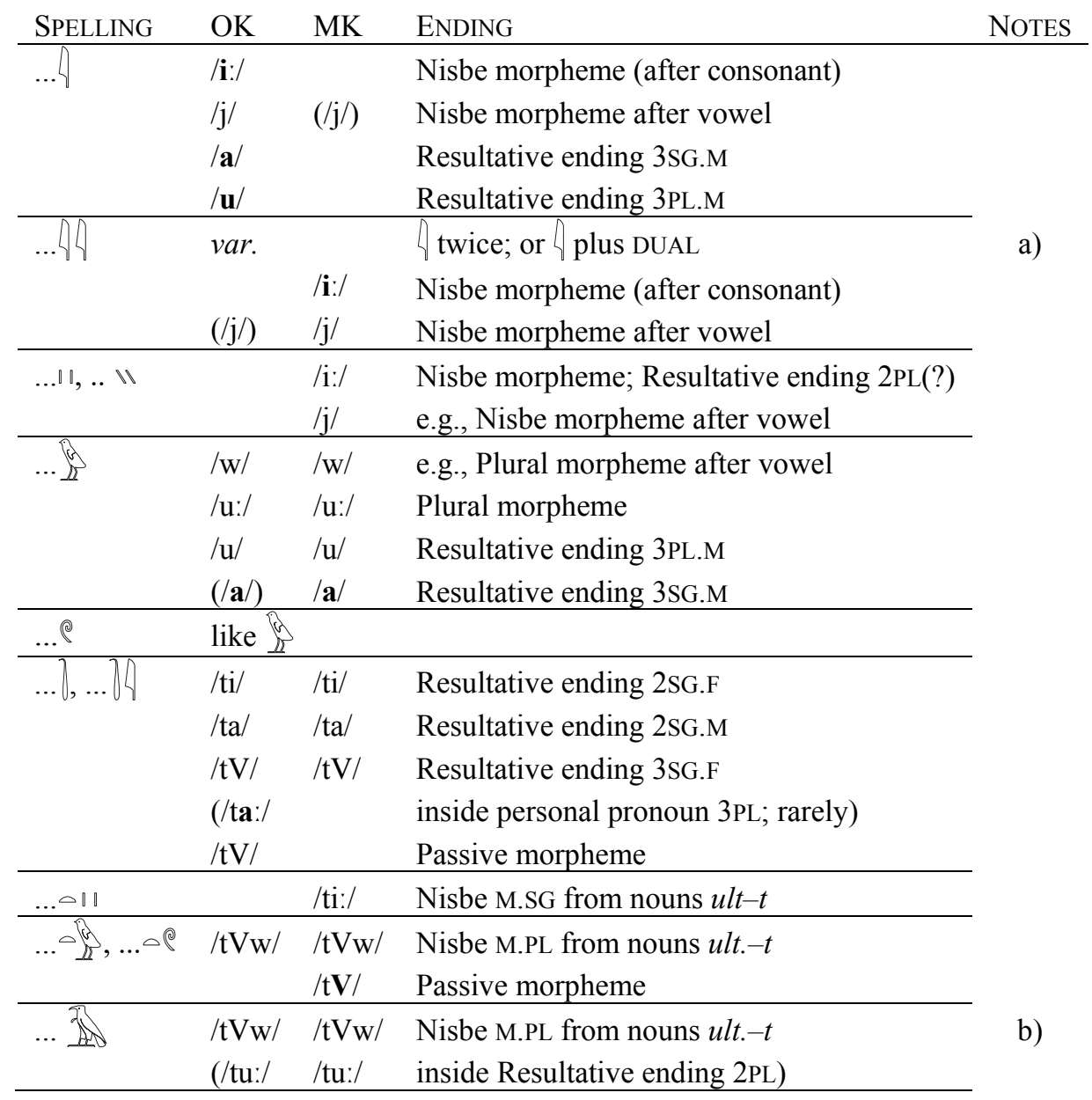

\section{Table notes}

a) For 4 in the OK, cf. Sethe 1899, I, §§ 121-121bis; Edel 1955-64, §§ 148, 150. Cf. also Allen 2013, 207 n. 2.

b) The reading of as $t w$, not $t i w$, is discussed in detail in Schultheiß 2014, chapter entitled "Zur Lesung des Zeichens 1."

Assuming that we are on the right track, the results have serious further consequences for the identification and interpretation of written forms, which have not yet been taken fully into account. For example, based on the spelling of the Resultative 3SG.M *sắçma /'sac'ma/ as $s \underline{d} m \boldsymbol{i}(\mathrm{OK})$ and $s \underline{d} m \boldsymbol{w}(\mathrm{MK})$, we would naturally conclude that $s \underline{d} m \boldsymbol{i}(\mathrm{OK})$ and $s \underline{d} m \boldsymbol{w}(\mathrm{MK})$ are possible writings not just for the Posterior

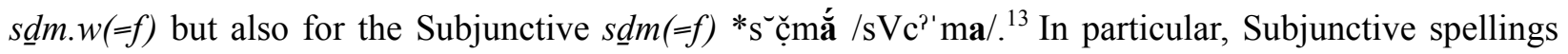
with final 8 might represent the auslaut $* /$ na/ as in NK syllabic spellings. ${ }^{14}$ This, by the way, puts even more analytic load on the variant spellings of the stem of verbs IIae gem. (Posterior $3 \mathbf{m m} / \mathrm{RV}$ ' $\mathbf{m V m V}$ / vs. Subjunctive $; \boldsymbol{m} / \mathrm{R} V \mathbf{m}$ ' $\mathbf{m a} /$ ) and on the syntactic construction.

13 That the final $w$ may hint at the final /'a/ in the (respective) verbal form is also assumed by Allen 2013, 114-15.

14 Kammerzell, in Hannig 1995, LV. 


\section{PART II. THE PRAGMATICS OF MATER LECTIONIS SPELLINGS: GLIMPSES AT READER- ORIENTED SPELLING PRACTICES; OR: WHY THE NISBE MORPHEME IS USUALLY SPELLED OUT IN THE M.SG OF DE-NOMINAL NISBES ONLY}

If we assume that matres lectionis are part of Earlier Egyptian orthographies, naturally the question arises: What considerations triggered the use of a mater lectionis as a reading aid? This is a complete change in perspective. Traditionally, on the basis of the Defective Spelling Hypothesis (which takes any glide as a hint at a consonant in a consonantal slot of the syllable structure), the question was: What triggers the omission of the consonantal glide grapheme? - which has never been satisfyingly addressed, in my opinion. On the basis of the Mater Lectionis Hypothesis, on the other hand, we ask: What triggers the inclusion of an orthographical hint at a vocalic phoneme? Now it is the written mark that is to be explained and not its omission.

An illuminating case, I argue(d), is that of the nisbe spellings in Earlier Egyptian orthographies. ${ }^{15}$ Based on selected evidence from Semitic languages, it is traditionally assumed that the nisbe morpheme was originally at least partially consonantal $* / \mathrm{Vj} /$, probably $* / \mathrm{i}: \mathrm{j} /$. There are, however, good reasons to assume that cases with consonantal $/ \mathrm{j} /$ in Semitic languages are secondary renderings $(* / \mathrm{i}: /+/ \mathrm{V} / \rightarrow * / \mathrm{i} ; \mathrm{j} /)^{.}{ }^{16}$ Indeed, the nisbe morpheme is not usually spelled out in standard Earlier Egyptian orthographies in the M.PL and in the F (see Table 1Error! Reference source not found.). The traditional "Consonantal Nisbe Hypothesis" cannot easily account for this fact. According to the "Mater Lectionis Hypothesis" (no. 1, above), however, these spellings suggest that the nisbe morpheme is a vowel rather than a consonant. The quality of the vowel in question is to be determined as */i/, very probably long */i:/ (Table 1Error! Reference source not found., $n$. o). The vocalic nature explains why it is not usually written. What needs to be accounted for in the light of the new "Vocalic Nisbe Hypothesis" is the comparatively common spelling of the morpheme in the M.SG (OK: $\hat{l} / t \vec{i}$; MK $\ddot{i}, y / t i)$.

According to the Mater Lectionis Hypothesis and the Fluctuating Guide Hypothesis (no. 5, below), we might assume that, as a secondary effect, the M.SG ending */i:/ was pronounced as *[ij] in some instances of the M.SG. There is, however, another solution: against the Mater Lectionis Hypothesis, we might still take the occasional spellings $i, i$, and $y$ as matres lectionis for vocalic */i:/. But how do we account for this exception? And why didn't the Egyptian scribes spell all the other nisbes (M.PL, F, ...) with a mater lectionis as well? An answer partially lies in the nature of matres lectionis itself. If the scribes did not use a mater lectionis in the M.SG, the reader could more readily misunderstand the written form. For example, she or he could misinterpret

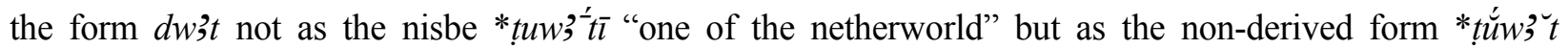
"netherworld." ${ }^{17}$ A spelling $d w$ ti $i$ with an additional mater lectionis $\ddot{i}$, however, solves the problem for the reader. The possibility of a misinterpretation, in contrast, is not present in the case of the spellings $d w$;tt and $d w$ 'tw, which can only be interpreted as the nisbes *tuw ${ }^{\prime}{ }^{\prime} t \bar{t} t$ and $*_{t}^{*} u w,{ }^{\prime} t \bar{t} w$, respectively. As opposed to the case of M.SG, a mater lectionis is usually simply not necessary in the case of M.PL and in the case of F. ${ }^{18}$

The Mater Lectionis Hypothesis also explains some other observations that I made in the text-specific orthography of the Book of Caverns (early Neo-Middle Egyptian; 19th Dynasty; Werning 2011, I, § 36).

15 Werning 2011, I, §§ 56-57.

16 Cf. Schultheiß 2014, Chap. 3.2 "Weitere Probleme mit Nisben," esp. Part (4).

17 Note that the use of classifiers may also inform the reader (cf. Werning 2011, I, § 37). Also note the interesting puzzle of the

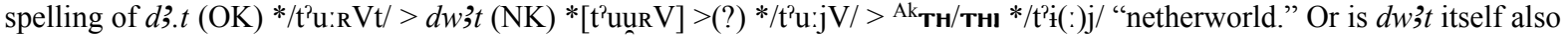
a spelling that renders a vowel: $d w ; t * / \mathrm{t}^{3} \mathrm{u}: \mathrm{RVt} /$ with $w ;$ for $* / \mathrm{u}: \mathrm{R} /$ ?

18 For the cases of nisbes M.PL and $\mathrm{F}$ based on nouns ult. non- $t$, see below. 
The spelling of nisbes in Caverns deviates from spellings in standard Middle Egyptian orthographies in that a mater lectionis $y$ is quite often used for the nisbe morpheme */i:/ not only in the M.SG, but also occasionally in the M.PL and the F - but only in nisbes based on nouns ult. non-t. ${ }^{19}$

Table 4: Spellings of nisbe endings in Earlier Egyptian and in the Book of Caverns

\begin{tabular}{|c|c|c|c|c|}
\hline NISBE ENDING & OK SPELLING & MK SPELLING & $\begin{array}{l}\text { BOOK OF CAVERNS } \\
(19 \mathrm{TH} \text { DYN.) }\end{array}$ & $\begin{array}{l}\text { RECON- } \\
\text { STRUCTION }\end{array}$ \\
\hline M.SG & $\begin{array}{l}\text { usually ø, also }\{(!) \text {; } \\
\text { rarely }\{\}\end{array}$ & 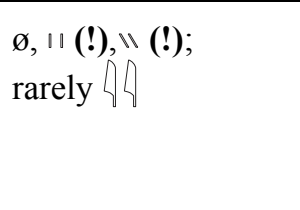 & $\begin{array}{l}\text { de-nominal: }\{4(!) \text {, } \\
\text { rarely ø; } \\
\text { de-prepositional: } \varnothing \text {, } \\
\text { rarely ı } ~\end{array}$ & $* / \mathrm{i}: /$ \\
\hline M.PL & $\begin{array}{l}\text { usually } 8 \text {; also } ø ; \\
\text { rarely } \& \text {; } \\
\text { (optionally plus } ₫ \nabla \text { or eq }\end{array}$ & R. @; also ø & $\begin{array}{l}\text { de-nominal: } 4 \mathcal{A} \text { (!), } \\
\text { rarely } \varnothing ; \\
\text { de-prepositional: } \\
\text { rarely } \varnothing\end{array}$ & */i:w/ \\
\hline $\mathrm{F}(\mathrm{SG} / \mathrm{PL})$ & 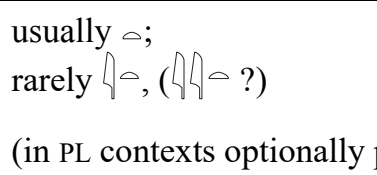 & lus $₫ \| \triangleleft$ or equivalent) & $\begin{array}{l}\text { de-nominal: }\{h \triangleright(!), \triangle \text {; } \\
\text { de-prepositional: }\end{array}$ & $* / \mathrm{i}: \mathrm{t} /$ \\
\hline $\begin{array}{l}\text { M.SG, nouns } \\
\text { ult. }-t\end{array}$ & $\begin{array}{l}\text { usually } \triangle \text {, also } 72 \text { or } 7(!) \text {, } \\
\text { rarely } \triangle \text {, } \triangle \text { Aी }\end{array}$ & $\triangle, \triangle \|$ & ०॥ (!); rarely & $* /$ ti:/ \\
\hline $\begin{array}{l}\text { M.PL, nouns } \\
u l t-t\end{array}$ & $\begin{array}{l}\text { usually } \\
\text { rarely } \triangle 1\end{array}$ & 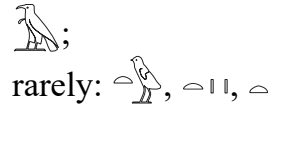 & 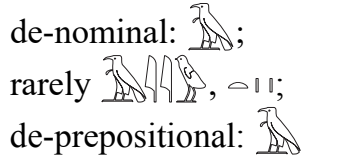 & */ti:w/ \\
\hline & (optionally plus $₫ \|$ or eq & ivalent) & & \\
\hline $\mathrm{F}(\mathrm{SG} / \mathrm{PL})$, nouns ult. $-t$ & $\begin{array}{l}\infty \\
\text { (in PL contexts optionally }\end{array}$ & $\begin{array}{l}\infty \\
\text { lus }\|\| \text { or equivalent) }\end{array}$ & $\infty$ & $* /$ ti:t/ \\
\hline
\end{tabular}

Why this rather complex pattern? Again, it is the reader-oriented purpose of a mater lectionis. In the case of de-prepositional nisbes, there is most often no need for a mater lectionis since (i) the spelling of the stem

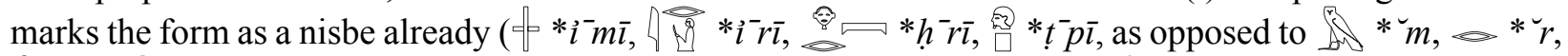
$* h r, r(\underline{p}$ ) or (ii) the bare fact that they have an inflectional ending $\triangle$ or marks the form as a derived

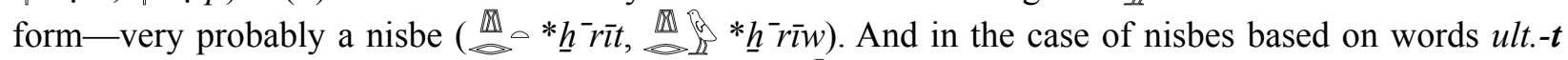
(nouns as well as prepositions), the spellings $\triangle$ and are indicative enough to identify them as nisbe forms ( $\mathrm{F} * . . . t \bar{t} t$, M.PL *...ti w). To make a complex story short: cum grano salis, a mater lectionis for the nisbe vowel $* / \mathrm{i}$ :/ is used in cases that could be misinterpreted by the reader if it was missing, but not necessarily in cases in which the nisbe form can easily be recognized as such by other clues.

I conclude with the following claim:

19 Other de-nominal nisbes as well as de-prepositional nisbes are usually spelled without mater lectionis, just as in standard Middle Egyptian orthographies. 


\section{Hypothesis 2 ("Spelling Pragmatics Hypothesis")}

If the distribution of spelling out and not spelling out of $\langle w\rangle,\langle i\rangle$, or $\langle y\rangle$ is in a systematic relation to the possibility or ease for the reader to identify the underlying form, the $\langle w\rangle,\langle i\rangle$, or $\langle y\rangle$ is likely to be a mater lectionis that hints at a vowel. ${ }^{20}$

This hypothesis may also identify the spellings of the $t$-based passive morpheme as $t \hat{\imath}(\mathrm{OK})$ and $t w(\mathrm{MK})$ as a mater lectionis spelling for $* / \mathrm{tV} /{ }^{21}$ In pPrisse, for example, $t$-based passives are spelled simply as $t$ if a personal suffix pronoun follows, but as $t w$ if no suffix pronoun follows (e.g. $s \underline{d} m t=\mathrm{vs} . s \underline{d} m t w) .{ }^{22}$ The fact that no mater lectionis is used if a personal suffix pronoun follows could be explained by the fact that, for example, the form $s \underline{d} m t=f$ may be recognized by the reader as $t$-passive more quickly than in the case of $s \underline{d} m t$ without suffix pronoun. Indeed, there is a high probability that a $s \underline{d} m t=f$ is one of only two forms, either a passive or a relative form. A $s \underline{d} m t$, however, may not only represent a passive or a relative form, but also a participle. A $s \underline{d} m t$ is (statistically) slightly more ambiguous than a $s \underline{d} m t=$ plus personal suffix pronoun. That the $w$ is used in the orthography of the $t$-Passive in pPrisse more often in more ambiguous instances than in less ambiguous instances may, therefore, further support the hypothesis that the optional $w$ in $t w$ is a reading aid, i.e. a mater lectionis (cf. Hypothesis 2).

So far we have seen that there are good reasons to assume that some of the spellings $i, \ddot{i}, y$, and $w$ are actually matres lectionis for various vowels in certain grammatical morphemes, and that some of these matres lectionis are triggered by reader-oriented considerations in individual texts ("spelling pragmatics").

\section{PART III. WHY SHOULD WE EVEN BOTHER ABOUT VOWELS, ANYWAY? OR: WHY THE IMPERFECTIVE RELATIVE FORM $s \underline{d} m \cdot w / y(=f)$ AND THE PASSIVE DISTRIBUTIVE PARTICIPLE $s \underline{d} m . w$ MAY INDEED BE ONE AND THE SAME FORM MORPHOLOGICALLY}

It is a well-known fact that certain forms exhibit spellings with $w$ in some cases, but $y$ in other cases. Two illuminating cases are the spelling of the nisbe of nouns ult.-w (e.g. hpr.w/y) and the spelling of Imperfective Relative Forms M.SG $s \underline{d} m . w / y .{ }^{23}$ Interestingly, the spellings of the nisbe of nouns $u l t .-w$ very often exhibit a $y$ instead of a $w$ :

Table 5: Spelling of nisbes based on nouns ult.-w

\begin{tabular}{|c|c|c|c|c|}
\hline \multicolumn{2}{|c|}{ NOUN ULT. $-w$} & \multicolumn{3}{|l|}{ NiSBE } \\
\hline$i w n \boldsymbol{w}^{\otimes}$ & "Heliopolis" & $i w n w^{2} y$ & "the Heliopolitan" & (Pyr. 483a P: "8h \\
\hline & & $i w n \boldsymbol{w}^{\otimes} \boldsymbol{y}^{\text {ती }}$ & "the Heliopolitan" & (CT VII, 221h: 100 h \\
\hline$b n \boldsymbol{w}^{\hat{P}^{3}}$ & "phoenix" & $b n \boldsymbol{y}^{\text {मी }}$ & "phoenix-like one" & $(H b .22 .25)$ \\
\hline$h f \boldsymbol{w}^{2 m}$ & "snake" & $h f \boldsymbol{y}^{\boldsymbol{y}^{\text {กी }}}$ & "snake-shaped one" & $(H b .67 .11)$ \\
\hline$n{ }^{r} \boldsymbol{w}^{2 m}$ & " $n\ulcorner w$-snake" & $n^{\ulcorner} \boldsymbol{w y}$ & " $n{ }^{r} w$-snake-shaped one" & $(H b .67 .10)$ \\
\hline hprw & "transformation" & hpry & "transformation-like one" & $(H b .75 .2,76.18)$ \\
\hline
\end{tabular}

This may effectively overrule the Mater Lectionis Hypothesis (no. 1, above).

Cf. Table 1, n. i) above.

Based on the transliteration of pPrisse encoded by Peter Dils in the TLA.

Schenkel 2008, 156-58; Schenkel 2009b, 262-63; Werning 2011, I, §§ 38, 59.

Edel 1955-64, § 344 (erroneously cited as iwnwy without classifier: cf. Leclant 2001, pl. XX, col. 51). 


\begin{tabular}{|c|c|c|c|c|}
\hline 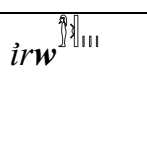 & "figure" & 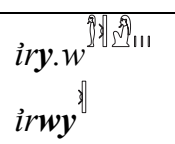 & $\begin{array}{l}\text { "figure-shaped ones" } \\
\text { "figure-shaped one" }\end{array}$ & $\begin{array}{l}(H b .59 .20) \\
(H b .63 .3)\end{array}$ \\
\hline$s d b \boldsymbol{w}^{10110}$ & "mischief" & $s d b y \cdot w^{\beta=2}$ & "ones destined to mischief" & $(H b .40 .1-4,42)$ \\
\hline
\end{tabular}

According to the Mater Lectionis Hypothesis and the Intervocalic Glide Axiom (Hypothesis 1 and Preassumption 1, above), the absence of the glide $w$ can only be explained by the hypothesis that the consonantal $w$ has somehow disappeared. Indeed, this usual disappearance of the $w$ can reasonably be explained as a phonetic effect. The nominal ending ... $w^{*} / \mathrm{Vw} /$ plus nisbe morpheme */i:/ forms an ending */V:wi:/, probably with a stress on the pre-final syllable (e.g. /'a:wi:/ or /'i:wi:/). Phonetically, it is plausible that the /w/ in the cluster/V:wi:/ turns into /j/ under the influence of the vowel/i:/ (phonetic assimilation); for example:

Table 6: Phonetic reconstruction of nisbes from nouns ult. $-w$

\begin{tabular}{|c|c|c|c|c|}
\hline NOUN ULT. $-W$ & & NISBE DERIVATION & & \\
\hline */?V'wa:nVw/25 & $\grave{l} w n \boldsymbol{w}$ & **/?Vwa:'nV:wi:/ & $>*[? V w a ' n V: j i:]$ & $i w n\{w\} \boldsymbol{y}$ \\
\hline */'bV:nVw/ & bnw & **/bV'nV:wi:/ & $>*\left[b V^{\prime} n V: j i:\right]$ & bny \\
\hline */'xupraw/ & hprw & **/xup'ra:wi:/ & $>*[$ xup'ra:ji: $]$ & hpry \\
\hline$* / \mathrm{sVt}^{2} \mathrm{bVw} /$ & $s d b \boldsymbol{w}$ & 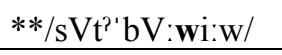 & $>*\left[\mathrm{sVt}^{2} \mathrm{bV}: \mathbf{j i}: \mathrm{w}\right]$ & $s d b \boldsymbol{y} w$ \\
\hline
\end{tabular}

Schenkel $(2008,167)$ observed the same effect in the case of the noun hprw before the personal suffix pronoun 1SG. Here, again, we can reconstruct a phonological cluster */a:wi:/ (ending */aw/ plus suffix pronoun $1 \mathrm{SG} * / \mathrm{i}: /):^{26}$

Table 7: Phonetic reconstruction of nouns ult. $-w$ plus personal suffix pronoun 1SG

\begin{tabular}{|c|c|c|c|c|}
\hline \multicolumn{2}{|c|}{ NOUN ULT. $-W$} & \multicolumn{3}{|c|}{ PLUS PERSONAL SUFFIX PRONOUN 1SG } \\
\hline \multirow[t]{2}{*}{ /'xupraw/ } & hprw & $* * /$ xup'ra:wi:/ > *[xup'ra:ji:] & 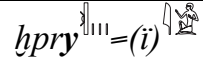 & (CT V, 242c S10C) \\
\hline & & & $h \operatorname{pry}=(i)^{\AA}$ & $(\mathrm{CT} \mathrm{IV}, 141 \mathrm{j} \mathrm{B7C})^{27}$ \\
\hline
\end{tabular}

The same effect can also be observed in the case of yet another grammatical formation: the Imperfective Relative Form $(s \underline{d} m . w / y)$. In this form, the ending $w$ usually turns into $y$ before the personal suffix pronoun $1 \mathrm{SG}\left({ }^{*} s \underline{d} m \boldsymbol{w} \rightarrow s \underline{d} m \boldsymbol{y}=(i){ }^{2}\right) .{ }^{28}$ The same, however, happens occasionally before mono-consonantal suffix pronouns. ${ }^{29}$ I suggest blaming the assimilating force of a following Bindevokal $* / \mathrm{i} /{ }^{30}$ before the personal suffix pronoun, which is only employed in the case of the mono-consonantal suffix pronouns (see Table 8 ). ${ }^{31}$

Cf. Schenkel 2008, 158 with n. 52.

Cf. Table 1Error! Reference source not found., nn. a) and m) above.

Schenkel 2008, 167.

Schenkel 2009b, 262; Werning 2011, I, § 59.

Schenkel 2009b, 262-63; cf. Schenkel 2000a, 97-98 for the comparable case of the Posterior.

Cf. Loprieno's approach (1995, 55-56), assuming an */i/ as an old genitive/possessive case ending.

I further hypothesize (i) that the vowel before the */w/ is a $* / \mathrm{u} /$ and (ii) that there is an optional contraction $* / \mathrm{uw} />[\mathrm{u}$ :] in order to explain the cases of spellings without any glide. Differently, Schenkel (2009b, 264-69) hypothesized a vocalization pattern */CV'CVCwV(C)/ (with mono-consonantal suffix pronoun) */CVCVC'wV:/ (other cases) and that it is a preceding consonant $r$ or $n$, more rarely probably $\underline{t}$ or $\underline{d}$, that triggers the change $w>y$. The same effect, however, is also attested in Caverns after $s$ before a $1 \mathrm{SG}$ personal suffix pronoun (nisy=(i)), which, admittedly, could be blamed on the pronoun. Anyhow, I am not ready to embrace Schenkel's hypothesis before I learn more on the assumed phonetic reason why specifically $r / \mathrm{r} /, n$ $/ \mathrm{n} /$, and probably $\underline{t} / \mathrm{c} /, \underline{d} / \mathrm{c}^{\mathrm{P}} /, \mathrm{C} / \mathrm{S} /$ (and $s / \mathrm{s} /$ ) ), but not,$/ \mathrm{R} /, \underline{h} / \mathrm{h} /, d / \mathrm{t} /$, (and $s / \mathrm{s} /$ ?) would trigger a change such as Schenkel 
Table 8: Phonetic reconstruction of the Imperfective Relative Form

\begin{tabular}{|c|c|c|c|c|c|}
\hline \multicolumn{4}{|c|}{ NON-CONTRACTED STEM } & \multicolumn{2}{|c|}{ OR CONTRACTED STEM } \\
\hline \multicolumn{6}{|c|}{ i) Strong verbs } \\
\hline$s \underline{d} m \boldsymbol{w}$ & */sVc?'V:muw/ & & & or $s \underline{d} m$ & $*\left[\mathrm{sV}^{\prime} \mathrm{c}^{2} \mathrm{~V}: \mathrm{mu}:\right]$ \\
\hline$\left((s \underline{d} m \boldsymbol{w}=(i))^{\underline{\rho^{2}}}\right.$ & */sVc?'V'mu:wi:/)) & 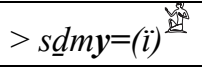 & $*\left[\mathrm{sVc}^{?} \mathrm{~V}^{\prime} \mathrm{mu}: \mathrm{ji}:\right]$ & or $s \underline{d} m=(y)^{\underline{v^{2}}}$ & $*\left[\mathrm{sV}^{\prime} \mathrm{c}^{?} \mathrm{Vmu}: \mathrm{j}\right]$ \\
\hline$(s \underline{d} m \boldsymbol{w}=k$ & */sVc' ${ }^{2}$ 'mu:wik/ & $>s \underline{d} m y=k$ & $\left.*\left[\mathrm{sVc}^{2} \mathrm{~V}^{\prime} \mathrm{mu}: \mathrm{jik}\right]\right)$ & or $s \underline{d} m=k$ & */sV'c ${ }^{?} \mathrm{Vmu}: \mathrm{k} /$ \\
\hline$s \underline{d} m \boldsymbol{w}=s n^{\prime \prime \prime}$ & */sVc ${ }^{2} V^{\prime} \operatorname{muwsin} /$ & & & (or $s \underline{d} m=s n^{110}$ & */sVc ${ }^{2} V^{\prime} m u: \sin /$ ) \\
\hline \multicolumn{6}{|c|}{ ii) Verbs IIIae-inf. } \\
\hline$m r r \boldsymbol{w}$ & */mV'rV:ruw/ & & & or $m r r$ & $*[\mathrm{mV}$ 'rV:ru: $]$ \\
\hline$\left(\left(m r r w=(i)^{)^{\mu^{2}}}\right.\right.$ & */mVrV'ru:wi:/)) & $>m r r y=(i)^{\text {涚 }}$ & $*[\mathrm{mVrV}$ 'ru:ji: $]$ & or $m r r=(y)^{\frac{y^{2}}{2}}$ & $*[\mathrm{mV}$ 'rVru:j] \\
\hline$(m r r \boldsymbol{w}=k$ & */mVrV'ru:wik/ & $>m r r y=k$ & $*[\mathrm{mVrV}$ 'ru:jik] $)$ & or $m r r=k$ & */mV'rVru:k/ \\
\hline$m r r \boldsymbol{w}=s n^{\prime \prime \prime}$ & */mVrV'ruwsin/ & & & (or $m r r=s n^{101}$ & */mVrV'ru:sin/) \\
\hline
\end{tabular}

This explanation for the phenomenon that an expected final $w$ may appear spelled out as $y$ in the case of the Imperfective Relative Form and in the case of the Posterior not just before the vocalic suffix pronoun of the $1 \mathrm{SG} * / \mathrm{i}$ // but also before mono-consonantal personal suffix pronouns, works - to spell it out explicitly — with the following hypothesis:

\section{Hypothesis 3 ("Personal Suffix Pronoun Attachment Hypothesis")}

Personal suffix pronouns are attached to their base in different ways, depending on whether the base ends with a vowel (thematic) or with a consonant (athematic). In the case of monoconsonantal suffix pronouns attached to an athematic base, there is need for a Bindevokal */i/.

\begin{tabular}{|c|c|c|c|c|}
\hline SUFFIX PRONOUN & \multicolumn{2}{|c|}{ AFTER CONSONANT } & \multicolumn{2}{|c|}{ AFTER VOWEL } \\
\hline Bi-consonantal, e.g. & */...Csin/ & $\ldots \mathrm{C}=s n^{\prime \prime \prime}$ & $* / \ldots V \sin /$ & $\ldots=s n^{\prime \prime \prime}$ \\
\hline $1 \mathrm{SG}$ & */...Ci:/ & $\ldots \mathrm{C}=(i)^{\underline{\mathrm{W}^{2}}}$ & $* / \ldots \mathrm{Vj} /$ & $\ldots=(y)^{\text {湿 }}$ \\
\hline Mono-consonantal, e.g. & $* / \ldots$ Cif/ & $\ldots \mathrm{C}=f$ & $* / \ldots \mathrm{Vf} /$ & $\ldots=f$ \\
\hline
\end{tabular}

Since we can explain the spellings of the Imperfective Relative Form with $y$ as a secondary phonetic effect that is triggered by a following /i:/ of */i/, the way is paved to argue that the Imperfective Relative Form $s \underline{d} m . w / s \underline{d} m . y=$ and the Passive Distributive Participle $s \underline{d} m . w$ are indeed one and the same form, not only etymologically but also synchronically, ${ }^{33}$ despite the different spellings of the forms ( $s \underline{d} m w / s \underline{d} m y$ vs. $s \underline{d} m w$ ).

The three cases discussed above support the following hypothesis:

\section{Hypothesis 4 (“/Vwi/ > /Vji/ Hypothesis”)}

A phonological cluster /Vwi(:)/ was pronounced as [Vji(:)] in certain varieties of Earlier Egyptian. This is an effect of assimilation of $/ \mathrm{w} /$ to the following $/ \mathrm{i}(:) / .^{34}$ The phonological

proposes $(2009 \mathrm{~b}, 269: r w * / 1 \mathrm{w} />*[1 \mathrm{j}]>*[\Lambda \kappa] ; n w * / \mathrm{nw} />*[\mathrm{nj}]>*[\mathrm{nn}])$; and I also wonder, if Schenkel's hypothesis is right, whether we wouldn't expect many more cases of $y$ in the spelling of other forms and words.

32 For the vocalization of the personal suffix pronouns themselves, cf. also Loprieno 1995, 63-64. For the 1sG, cf. Table 1Error! Reference source not found. $\mathrm{nn}$. a) and $\mathrm{m}$ ) above.

33 Cf. the references in Werning 2011, I, 96 n. 37.

34 Probably only after certain stressed vowels. 
effect may be represented by the spelling $y$ or by the "hybrid" spelling $w y$ (as a hint at the change $*[w]>*[j])$.

More generally, we have seen that there is good reason to assume that phonology and phonetic effects are possibly properly represented in spelling, i.e., that not all spellings are "frozen" orthography. This - I take it - urges us to address the question of "frozen" orthography and phonetic spelling in grammatical morphemes/endings more thoroughly. ${ }^{35}$

\section{PART IV. THE FUNCTIONS OF $y$; \\ OR: LET'S STOP IDENTIFYING ANY y AS AN “ENDING” BY DEFAULT}

Traditionally, a spelling $y$ is most often identified as part of an ending or inflection, either explicitly or by the transliteration as " $y$ " with a separating dot. ${ }^{36}$ There are, however, quite a few different possibilities ${ }^{37}$ that are not always thoroughly considered as an option:

1) Spelled after or instead of $, r, w$, or ${ }^{\ulcorner}(?)$, the grapheme $i$ or $y$ might indicate a sound change:

i),$y \sim y / \mathrm{R} />/ \mathrm{j} /(\mathrm{cf}$. Werning 2011, I, § 52), for example in

$\check{s} t\{$ \} $\}$ y. $t$ "mysterious" (F.SG) (Caverns),

‘\{3\}y.t "great" (F.PL) (Caverns),

\{\{3\}y(.w)/ $\{\{\boldsymbol{3}\} \boldsymbol{y}(. t)$ "great" (PL) (NK);

ii) $r i \sim i$ or $r y \sim y / \mathrm{r} />/ \mathrm{j} /$, for example in

$z w r \sim z w\{\boldsymbol{r}\} \boldsymbol{i} \sim z w i$ “drink" (DZA 28.584.200-240),

Hpr $H_{p}\{\boldsymbol{r}\} \boldsymbol{i} \sim H p i$ “Khepri; the Transforming one” (Werning 2008a, 130-31; 2011, II, 504),

‘r $\boldsymbol{r} \boldsymbol{i} . t(i)=f$ "his jaws" $(H b .39 .17)$,

$\underline{d} s\{\boldsymbol{r}\} \boldsymbol{y}, \underline{d} s\{\boldsymbol{r}\} \boldsymbol{y} . w, \underline{d} s\{\boldsymbol{r}\} \boldsymbol{y} . t$ "sacral" (Book of Gates; Werning 2011, I, § 53);

iii) $w y \sim y / \mathrm{w} />/ \mathrm{j} /$, for example in

$\check{s} n\{\boldsymbol{w}\} \boldsymbol{y} t=f$ "his entourage" (Hb. 10.15; cf. Werning 2011, I, § 63), šnwt > šnyt "entourage" (DZA 30.157.810-30),

cf. also part III above;

and probably, I argue,

iv) $\mathcal{C} / \mathrm{S} />*[2]^{38}$, esp. in the neighborhood of $h$ (and $h$ ?), for example, in Caverns (cf. Werning 2011, I, $\S \S 80,84$, with additional reference to the case of certain Late Egyptian spellings):

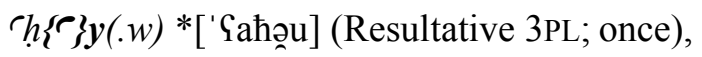

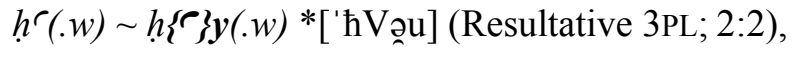

$$
\begin{aligned}
& h\left\ulcorner( . w ) \sim h \left\{\boldsymbol{r} \boldsymbol{y}(. w) *\left[' \hbar V_{\partial} \mathrm{V}\right]\right.\right. \text { (Imperative PL; 3:1). }
\end{aligned}
$$

This and other spelling phenomena in Caverns provide evidence that the authors still had their own precise ideas about the pronunciation of Egyptien de tradition forms such as the Imperfective Relative in the 19th Dynasty (for the date of Caverns, cf. Werning 2011, I, Chap. V).

36 The dot, however, is sometimes used even explicitly against better knowledge (cf., for example, Schenkel 2000a, 69).

37 Cf. the discussion of Late Egyptian spellings by Schenkel 1994b.

38 Cf. Peust 1999, 100, with reference to Kammerzell in Hannig 1995, L. 
2) A $y$ might represent a consonantal realization of the ult. inf. glide of a verbal root in certain forms, for example the Subjunctive */sVc 'ma/ $s \underline{d m}$, but */cVs'ja/ $\underline{t} s y \sim * / \mathrm{cVs}$ 'ia/ $\underline{t} s(i)$ "may raise" (cf. Schenkel 1994b, 13; 2000a, 68; 2012, 215).

I support the hypothesis that the ult. inf. glide of a verbal root may either surface as $i / y *[j]$ or not $\varnothing$ *[i] (cf., for example, Schenkel 2000a, 68). Actually, I support the following more general hypothesis: ${ }^{39}$

\section{Hypothesis 5 ("Umphonetisierungshypothese" / "Fluctuating Glide Hypothesis"):}

A phonological glide may be spoken as consonant and surface as $i / y *[\mathrm{j}]$ or $w *[\mathrm{w}]$, respectively, or it may be spoken as vowel $*[i(:)]$ or $*[u(:)]$, respectively, without written representation. The possibility of a realization as consonant or vowel, respectively, is dependent on its position in the syllable structure. ${ }^{40}$

3) A $y$ might be a mater lectionis for vocalic /i:/ (or a similar closed frontal vowel) in the specific orthographies of certain texts, for example in the Book of Caverns (19th Dyn., early Neo-Middle Egyptian), see Part II above.

As a consequence, for example in verbal forms of verbs ult.-i-inf. and verbs whose last non-inf. consonant is $,, r, w$, or ' , an immediately following $y$ is quite unclear as far as its interpretation is concerned. For

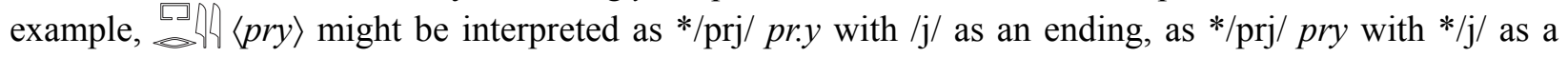
realization of the ult. inf. glide, as $* / \mathrm{pj} / p\{r\} y$ (or even $* / \mathrm{prj} / p r\{r\} y$ ) with $* / \mathrm{j} /$ as a reflection of a sound change, or, for example in Caverns, even as */pri:/ pr.y with $y$ as a mater lectionis. The acknowledgement of this may have quite an impact on morphological analyses as far as the number of clearly illuminating cases are concerned. ${ }^{41}$ The judgment has always to be made depending on the observed individual orthographic system of the respective text.

\section{CONCLUDING REMARKS}

We have seen that there are good reasons to assume

1) that some of the spellings $i, \ddot{i}, y$, and $w$ are actually matres lectionis for various vowels in certain grammatical morphemes (Part I, especially Table 3);

2) that some of these matres lectionis are triggered by reader-oriented considerations in individual texts ("spelling pragmatics"; Part II);

and we saw

3) that, in some cases, phonetic changes triggered by inflectional and derivational combination of morphemes are regularly reflected in the spelling of glides (Part III), and

4) how this makes the attribution of glide spellings to either the root or an ending more complicated than often considered (Part IV).

39 Cf. also Schenkel 1983, 189; Reintges 1997, 214-15. For a comparable phenomenon in Indo-European languages, cf. Barber 2013, 1-2, 377, 381.

40 Cf., for example, my Intervocalic Glide Axiom (Pre-assumption 1, above).

41 E.g. in Schenkel's (2000a, Tables 4 and 5) discussion of Subjunctives after a form of $r \underline{r}(\hat{i})$ that are spelled with $y, 19$ of 27 verb instances with $y$ are instances of verbs with a pre-final consonant,$r r$ or $w(h \xi y, \check{s} w y, i r y, p r y, m r y, h r y)$. This leaves only 8 instances of the verbs $s b y, h \xi b y, h s y, \underline{t} s y, k s i$ (plus one erroneous $b n\{y\}$ ), which clearly support this part of his argument on the reflection of the ult. inf. glide in the subjunctive as */CVC'ja/ CC $y \sim * / C V C ' i a / C C(i)$. For a similar problem concerning Late Egyptian verbal morphology, cf. Schenkel 1994b. 
In each of the four parts above, we have seen how far a set of hypotheses on the vocalization of forms and a set of hypotheses on the relation of spoken form to hieroglyphic spelling that includes the idea of matres lectionis in spellings of endings(!) in Earlier Egyptian may explain certain phenomena more naturally than the traditional theory. Compare, for example, the following reanalysis of the "problematic" forms from the beginning of this paper (Part I):

\begin{tabular}{|c|c|c|c|}
\hline \multirow[t]{2}{*}{;mm.t=f/,mm.tw $=f$} & 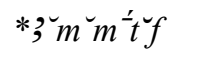 & \multicolumn{2}{|l|}{ */RVmV'mV:tVf/ } \\
\hline & 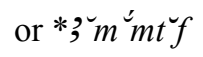 & */RV'mVmtVf/; & \\
\hline $3 m . t=f / 3 m \cdot t w=f$ & 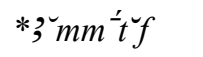 & */RVm'mV:tVf/; & \\
\hline pri. $t=f /$ pri.tw $t w=f$ & 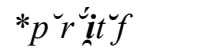 & */pV'rV:tVf/ (?) & \\
\hline & or * $p^{\sim} r i_{i}^{-} t \leftarrow f$ & */pV'rV:tVf/ (?). & \\
\hline ,h 'spirit' & 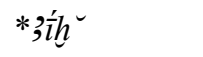 & */'ri:xV/ & $>{ }^{\mathrm{A} 2} 12 \sim{ }^{\mathrm{B}} 1{ }^{42}$, \\
\hline ;h.w / , hh(.w) "spirits" & 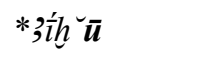 & */'RixVu:/ > *['Ri:xVW];;3 & \\
\hline it "father" & *iát & */'ja:tV/ & $>{ }^{\mathrm{SB}} \mathbf{E I \omega T}$ \\
\hline it.w / it(.w) "fathers" & *iát $\breve{\boldsymbol{u}}$ & */'ja:tVu:/ > *['ja:tVW] > (?) & $>{ }^{\mathrm{S}} \mathbf{E I O T E}$ \\
\hline hrw "day" & *hắrw & */'harwV/ > */'hawwV/ & 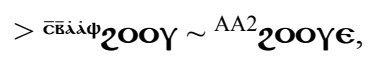 \\
\hline$h r(w) \cdot w$ "days" & ${ }^{*} h a r w \stackrel{\llcorner}{\boldsymbol{u}}$ & **/har'wuu:/ > *[har' ruw](?) & $>{ }^{\mathrm{AA} 2} 2 \mathrm{PE} \gamma$ \\
\hline
\end{tabular}

While the traditional theory often cannot easily explain the attested hieroglyphic spellings in a natural way (see Part I above), the reconstructions proposed here that are based on the set of hypotheses mentioned above are much more in line with the attested spellings. ${ }^{44}$

As a veritable "(complex) hypothesis," the set of hypotheses outlined above makes predictions about expected spellings which can be tested (this is much less the case for the traditional Defective Spelling Hypothesis). It also generates new questions; for example: Why do the spellings of the Posterior of verbs ult. inf. with 1SG personal suffix pronoun (and, equally puzzling, spellings of the Imperfective Relative Form with $1 \mathrm{SG}$ personal suffix pronoun) not always exhibit a $y\left(* * / \ldots{ }^{\prime} \mathrm{V}:\right.$ wi:/ $>* / \ldots{ }^{\prime} \mathrm{V}: \mathrm{ji}: /$; compare my suggestions in Part III above)?; or, Are productively derived forms, such as, for example, plurals, ${ }^{45}$ necessarily in line with the traditional syllable structure "rules"? An interesting puzzle! — in which hypotheses on vocalized forms and the spelling of glides and hints on vowels (i.e., matres lectionis) have a part to play!

\section{ABBREVIATIONS}

$\begin{array}{llll}\text { DU } & \text { dual } & \text { MK } & \text { Middle Kingdom } \\ \text { F } & \text { feminine } & \text { NK } & \text { New Kingdom } \\ \text { gem. } & \text { geminatae } & \text { OK } & \text { Old Kingdom } \\ H b . & \text { See Werning } 2011 \text { (vol. 2) in the Bibliography } & \text { PL } & \text { plural } \\ \text { inf. } & \text { infirmae } & \text { SG } & \text { singular } \\ \text { M } & \text { masculine } & \text { ult. } & \text { ultimae }\end{array}$

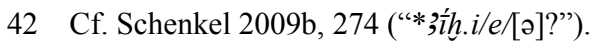

43 For this plural formation hypothesis, which operates with thematic nouns and a vocalic plural phoneme, cf. Werning 2011, I, $\S \S 65 \mathrm{a}-\mathrm{b}$.

44 The only case that the new theory cannot easily explain is the main vowel in some Coptic plural forms such as ${ }^{\mathrm{S}} \mathbf{\epsilon} \mathbf{0} \mathbf{6}$ "fathers." However, for an evaluation of the traditional Pre-Coptic Syllable Structure Rules Hypothesis and the Pre-Coptic Vowel Length Rule Hypothesis, cf. Peust 1999, Chap. 4 and Appendix 4; Schweitzer 2000.

45 Cf. the discussion in Werning 2011, I, § 65a-b. 


\section{BIBLIOGRAPHY AND TEXT SOURCES}

Adamson, Sylvia, and Wendy Ayre-Bennett

2011 "Linguistics and Philology in the Twenty-First Century: Introduction," Transactions of the Philological Society 109.3, 201-206.

Allen, James P.

1984 The Inflection of the Verb in the Pyramid Texts. Bibliotheca Aegyptia 2. Malibu.

1991 "Form, Function and Meaning in the Early Egyptian Verb," Lingua Aegyptia 1, 1-32.

1994 "Pronominal Rhematization," in David P. Silverman, ed., For His Ka: Essays Offered in Memory of Klaus Baer (Studies in Ancient Oriental Civilization 55; Chicago), 1-13.

2000 Middle Egyptian: an Introduction to the Language and Culture of Hieroglyphs. Cambridge.

2002 The Heqanakht Papyri. Publications of the Metropolitan Museum of Art Egyptian Expedition 27. New York.

2004 "Traits dialectaux dans les Textes des Pyramides du Moyen Empire," in Susanne Bickel and Bernard Mathieu, ed., D'un monde à l'autre: Textes des Pyramides et Textes des Sarcophages, actes de la table ronde internationale "Textes des Pyramides versus Textes des Sarcophages," IFAO 24-26 septembre 2001 (Bibliothèque d'étude 139; Cairo), 1-14.

2005 The Ancient Egyptian Pyramid Texts, ed. by Peter Der Manuelian. Writings from the Ancient World 23. Atlanta and Boston.

2006 "Some Aspects of the Non-royal Afterlife in the Old Kingdom," in Miroslav Bárta, ed., The Old Kingdom Art and Archaeology. Proceedings of the Conference Held in Prague, May 31 - June 4, 2004 (Prague), 9-18.

2010 Middle Egyptian: an Introduction to the Language and Culture of Hieroglyphs, 2nd ed. Cambridge.

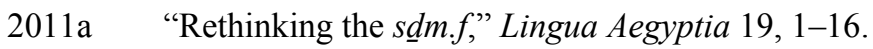

2011b The Debate Between a Man and his Soul: a Masterpiece of Ancient Egyptian Literature. Culture and History of the Ancient Near East 44. Leiden.

2013 The Ancient Egyptian Language, an Historical Study. Cambridge.

2014 "Emphatic Sentences and Nominal/Relative Forms in Earlier Egyptian," Lingua Aegyptia 21, 1-7.

2015 Middle Egyptian Literature: Eight Literary Works of the Middle Kingdom. Cambridge.

Altenmüller, Hartwig

1998 Die Wanddarstellungen im Grab des Mehu in Saqqara. Archäologische Veröffentlichungen, Deutsches Archäologisches Institut, Kairo 42. Mainz.

2011 "Reden und Rufe auf zwei Gräberbilddern des Alten Reiches," in Frank Feder et al., ed., Von Theben nach Giza: Festmiszellen für Stefan Grunert zum 65. Geburtstag (Göttinger Miszellen, Beihefte 10; Göttingen), 19-22.

Amenemhet Wolfgang Helck. Der Text der "Lehre Amenemhets I. für seinen Sohn." Kleine Ägyptische Texte 1. Wiesbaden, 1969.

Anthes, Rudolf

1930 Eine Polizeistreife des Mittleren Reiches in die westliche Oase," Zeitschrift für Ägyptische Sprache und Altertumskunde 65, 108-14.

Arnott, D. W.

$1970 \quad$ The Nominal and Verbal System of Fula. Oxford.

Assmann, Jan

1997 Das Kulturelle Gedächtnis: Schrift, Erinnerung und politische Identität in frühen Hochkulturen, Munich. 
(Assmann, Jan)

2002 Altägyptische Totenliturgien I: Totenliturgien in den Sargtexten des Mittleren Reiches. Supplemente zu den Schriften der Heidelberger Akademie der Wissenschaften, Philosophisch-historische Klasse, 14. Heidelberg.

Badawy, Alexander

1976 The Tombs of Iteti, Sekhem'ankh-Ptah and Kaemnofert at Giza. University of California Publications: Occasional Papers 9: Archaeology. Los Angeles.

Baer, Klaus

1966 "A deed of endowment in a letter of the time of Ppjj I?," Zeitschrift für Ägyptische Sprache und Altertumskunde 93, 1-9.

Baerman, Matthew

2004 "Directionality and (Un)natural Classes in Syncretism," Language 80, 807-27.

Baerman, Matthew, Dunstan Brown, and Greville G. Corbett

2005 The Morphology-Syntax Interface: A Study of Syncretism. Cambridge Studies in Linguistics 109. Cambridge.

Baker, Mark

1985 "The Mirror Principle and Morphosyntactic Explanation,” Linguistic Inquiry 16, 373-415.

Bakir, Abd el-Mohsen

1970 Egyptian Epistolography from the Eighteenth to the Twenty-first Dynasty. Bibliothèque d'étude 48. Cairo.

Barbash, Yekaterina

2011 The Mortuary Papyrus of Padikakem. Walters Art Museum 551. Yale Egyptological Studies 8. New Haven. Barber, Peter J.

2013 Sievers' Law and the History of Semivowel Syllabicity in Indo-European and Ancient Greek. Oxford Classical Monographs. Oxford.

Barns, John W. B.

1956 Five Ramesseum Papyri. Oxford.

Baud, Michel and Dominique Farout

2001 “Trois biographies d'Ancien Empire revisitées," Bulletin de l'Institut Français d'Archéologie Orientale 101, 43-57.

Bauer see Peas.

BD Nu Günther Lapp, Catalogue of Books of the Dead in the British Museum, I. The Papyrus of Nu (BM EA 10477). London, 1997.

Beaver, David, and Cleo Condoravdi

2003 "A Uniform Analysis of before and after," in Robert B. Young and Yuping Zhou, ed., Proceedings from Semantics and Linguistics Theory 13 (SALT) (Ithaca), 37-57.

Bendjaballah, Sabrina and Chris H. Reintges

2009 "Ancient Egyptian Verbal Reduplication: Typology, Diachrony, and the Morphology-Syntax Interface," in Bernhard Hurch and Veronika Mattes, ed., Special Issue on Reduplication: Diachrony and Productivity (Morphology 19), 135-57.

Beni Hasan Percy E. Newberry, Beni Hasan. 4 vols. Egypt Exploration Fund 1-2, 5, 7. London, $1893-1900$.

Berlin

1911 Hieratische Papyrus aus dem Königlichen Museen zu Berlin III: Schriftstücke der VI. Dynastie aus Elephantine; Zaubersprüche für Mutter und Kind; Ostraka. Leipzig, 1911.

Boeser, Pieter

1909 Beschrijving van de Egyptische Verzameling in het Rijksmuseum van Oudheden te Leiden, II. Den Haag. 
Bolinger, Dwight

1977 The Form of Language. London.

1985 "The Inherent Iconism of Intonation," in John Haiman, ed., Iconicity in Syntax (Typological Studies in Language 6; Amsterdam and Philadelphia), 97-108.

Borghouts, Joris

1989 "Aspectual Values of the Second Tenses in Middle Egyptian," in Silvia Schoske et al., ed., Linguistik, Philologie, Religion. Akten des vierten Internationalen Ägyptologen-Kongresses, München 1985 (Studien zur Altägyptischen Kultur, Beihefte 3; Hamburg), 29-42.

2010 Egyptian, an Introduction to the Writing and Language of the Middle Kingdom 1: Grammar, Syntax and Indexes. Egyptologische Uitgaven 24. Leuven and Leiden.

Bresnan, Joan, and Sam A. Mchombo

1987 “Topic, Pronoun, and Agreement in Chichewa,” Language 63, 741-82.

Brose, Marc

2014 Grammatik der dokumentarischen Texte des Mittleren Reiches. Lingua Aegyptia Studia Monographica 13. Hamburg.

Brovarski, Edward J.

2001 Giza Mastabas, 7. The Senedjemib Complex, I: The Mastabas of Senedjemib Inti (G 2370), Khnumenti ( $G$ 2374), and Senedjemib Mehi (G 2378), 2 vols. Boston.

Buchberger, Hannes

1995 "Das Harfnerlied im Grab $k$ ’ $(=i)-m$ - ${ }^{\prime} h \underline{h}$ oder 'Die Riten des $s n n t r w$ ',' in Dieter Kessler and Regine Schulz, ed., Gedenkschrift für Winfried Barta: htp dj $n$ ḥzj (Münchener Ägyptologische Untersuchungen 4; Frankfurt am Main), 93-123.

Butt, John, and Carmen Benjamin

2011 A New Reference Grammar of Modern Spanish, 4th ed. London.

Bybee, Joan L.

1985 "Diagrammatic iconicity in stem-inflection relations," in John Haiman, ed., Iconicity in Syntax (Typological Studies in Language 6; Amsterdam and Philadelphia), 11-48.

2010 Language, Usage, and Cognition. Cambridge.

Cairo CG 1-1294: Ludwig Borchardt, Statuen und Statuetten von Königen und Privatleuten im Museum zu Kairo, Nr. 1-1294. Catalogue général des antiquités égyptiennes du Musée du Caire. Berlin, 1911-36.

20001-20780: Hans O. Lange and Heinrich Schaefer, Grab-und Denksteine des Mittleren Reichs, 4 vols. Catalogue général des antiquités égyptiennes du Musée du Caire 51-54. Berlin, 1902-25.

Cannuyer, Christian

1990 "Recherches sur l'onomasiologie du feu," Zeitschrift für Ägyptische Sprache und Altertumskunde 117, 103-11.

Carnarvon, George E. S. M. H., Earl of, and Howard E. Carter

1912 Five Years' Exploration at Thebes: a Record of Work Done 1907-1911. London and New York. Chafe, Wallace

1994 Discourse, Consciousness, and Time: the Flow and Displacement of Conscious Experience in Speaking and Writing. Chicago.

1995 “The Realis-Irrealis Distinction in Caddo, the Northern Iroquoian Languages, and English,” in Joan L. Bybee and Suzanne Fleischman, ed., Modality in Grammar and Discourse. (Typological Studies in Language 32; Amsterdam and Philadelphia), 349-65.

Cherpion, Nadine, Jean-Pierre Corteggiani, and Jean-François Gout

2007 Le tombeau de Pétosiris à Touna el-Gebel. Bibliothèque générale 27. Cairo. 
Chierchia, Gennaro

2013 Logic in Grammar. Polarity, Free Choice, and Intervention. Oxford Studies in Semantics and Pragmatics 2. Oxford.

Chomsky, Noam

1981 Lectures on Government and Binding: The Pisa Lectures. Studies in Generative Grammar 9. Dordrecht.

1995 The Minimalist Program. Current Studies in Linguistics 28. Cambridge, MA.

2001 "Derivation by Phase," in Michael Kenstowicz, ed., Ken Hale: a Life in Linguistics (Current Studies in Linguistics 36; Cambridge, MA), 1-52.

Cinque, Guglielmo

1999 Adverbs and Functional Heads, a Cross-Linguistic Perspective. Oxford Studies in Comparative Syntax. Oxford.

Clère, Jacques Jean

1995 Les chauves d'Hathor. Orientalia Lovaniensia Analecta 63. Louvain.

Collier, Mark A.

1990 "The Circumstantial $\underline{\underline{d}} \underline{\boldsymbol{d}} m(. f) / \underline{\underline{d}} \boldsymbol{d} m . n(. f)$ as Verbal Verb-Forms in Middle Egyptian," Journal of Egyptian Archaeology 76, 73-85.

1991 "Circumstantially Adverbial? The Circumstantial $s \underline{d} m(. f) / s \underline{d} m . n(f)$ Reconsidered," in Stephen Quirke, ed., Middle Kingdom Studies (New Malden), 21-50.

1992 "Predication and the Circumstantial $\operatorname{sd} m(. f) / s \underline{d} m . n(f), "$ Lingua Aegyptia 2, 17-65.

1994 "Grounding, Cognition and Metaphor in the Grammar of Middle Egyptian: the Role of Human Experience in Grammar as an Alternative to the Standard Theory Notion of Paradigmatic Substitution," Lingua Aegyptia 4, 57-87.

Collier, Mark A., and Stephen Quirke

2002 The UCL Lahun Papyri: Letters. BAR International Series 1083. London.

Collombert, Philippe, and Laurent Coulon

2000 "Les dieux contre la mer: le début du 'papyrus d'Astarté' (pBN 202)," Bulletin de l'Institut Français d'Archéologie Orientale 100, 193-242.

Comrie, Bernard

1976 Aspect: an Introduction to the Study of Verbal Aspect and Related Problems (Cambridge Textbooks in Linguistics). Cambridge.

1977 Tense. Cambridge Textbooks in Linguistics. Cambridge.

1982 "Aspect and Voice: Some Reflections on Perfect and Passive," in Philip Tedeschi and Annie Zaenen, ed., Tense and Aspect (Syntax and Semantics 14; New York), 65-78.

Corbett, Greville G.

2006 Agreement. Cambridge Textbooks in Linguistics. Cambridge.

Croft, William

1996 "What's a Head?," in Johan Rooryck and Laurie Zaring, ed., Phrase Structure and the Lexicon (Studies in Natural Language and Linguistic Theory 33; Dordrecht), 35-75.

2001 Radical Construction Grammar: Syntactic Theory in Typological Perspective. Oxford.

CT

I-VII Adriaan de Buck, The Egyptian Coffin Texts, 7 vols. Oriental Institute Publication 34, 49, 64, 67, 72, 81, 87. Chicago, 1935-61.

VIII James P. Allen, The Egyptian Coffin Texts, VIII: Middle Kingdom Copies of Pyramid Texts. Oriental Institute Publications 132. Chicago, 2006.

Cysouw, Michael

2003 The Paradigmatic Structure of Person Marking. Oxford. 
2010 "Semantic Maps as Metrics on Meaning," Linguistic Discovery 8, 70-95.

Czerwik, Dorota

1999 "Some Remarks on the Letters to the Dead from the First Intermediate Period," Göttinger Miszellen 173, 61-66.

Dahl, Östen

1979 “Typology of Sentence Negation,” Linguistics 17, 79-106.

1985 Tense and Aspect Systems. Oxford.

David, Arlette

2006 Syntactic and Lexico-Semantic Aspects of the Legal Register in Ramesside Royal Decrees. Göttinger Orientforschungen IV, 38. Wiesbaden.

Davies, Norman de Garis

1943 The Tomb of Rekh-mi-Re“ at Thebes, 2 vols. Publications of the Metropolitan Museum of Art Egyptian Expedition 11. New York.

Depuydt, Leo

1986 "The Emphatic Nominal Sentence in Egyptian and Coptic," in Gerie Englund and Paul J. Frandsen, ed., Crossroad: Chaos or the Beginning of a New Paradigm. Papers from the Conference on Egyptian Grammar, Helsingør 28-30 May 1986 (Copenhagen), 91-117.

1988 "New Horizons in Coptic and Egyptian Linguistics," in Chronique d'Égypte 63 (126), 391-406.

1991 "On Distinctive and Isolating Emphasis in Egyptian and in General," Lingua Aegyptia 1, 33-56.

2008a The Other Mathematics: Language and Logic in Egyptian and in General. Piscataway, NJ.

2008b "Zum Nebeneinander von An- und Abwesenheit der Gemination in der Wendung mrjj jt.f mrrw snw.f," Lingua Aegyptia 16, 27-38.

2011 "Zu Lehr- und Lernbarkeit des ägyptischen Verbs: Wie viele typisch mittelägyptische $s \underline{d}$ ' $f$-Formen gibt es eigentlich? Neun!," in Alexandra Verbovsek et al., ed., Methodik und Didaktik in der Ägyptologie: Herausforderungen eines kulturwissenschaftlichen Paradigmenwechsels in den Altertumswissenschaften. (Ägyptologie und Kulturwissenschaft 4; München), 481-508.

Derchain-Urtel, Maria-Theresa

1973 “Das n-Präfix im Ägyptischen,” Göttinger Miszellen 6, 39-54.

Desclaux, Vanessa

2014 "Les appels aux passants en Égypte ancienne: approche historique d'un genre littéraire," 2 vols. Thèse de doctorat, Université de Lyon II.

Di Biase Dyson, Camilla

2012 "A Diachronic Approach to the Syntax and Semantics of Egyptian Spatio-temporal Expressions with $h$; $-t$ 'front': Implications for Cognition and Metaphor," in Eitan Grossman et al., ed., Lexical Semantics in Ancient Egyptian (Lingua Aegyptia Studia Monographica 9; Hamburg), 247-92.

Di Biase Dyson, Camilla, Frank Kammerzell, and Daniel Werning

2009 "Glossing Ancient Egyptian: Suggestions for Adapting the Leipzig Glossing Rules," Lingua Aegyptia $17,343-66$.

Díaz Hernández, Roberto A.

2013 Tradition und Innovation in der offiziellen Sprache des Mittleren Reiches: ein strukturalistischer Vergleich der historisch-biographischen mit den literarischen Texten in der 1. Zwischenzeit und der 12. Dynastie. Göttinger Orientforschungen IV, 56. Wiesbaden.

Dixon, Robert M. W.

2004 “Adjective Classes in Typological Perspective," in Robert M. W. Dixon und Alexandra Y. Aikhenwald, ed., Adjective Classes: a Cross-Linguistic Typology (Oxford), 1-49. 
Donnat Beauquier, Sylvie

2009 "Le rite comme seul référent dans les lettres aux mort," Bulletin de l'Institut Français d'Archéologie Orientale 109, 61-93.

2014 Écrire à ses morts: enquête sur un usage rituel de l'écrit dans l'Égypte pharaonique. Grenoble.

Doret, Éric

1986 The Narrative Verbal System of Old and Middle Egyptian. Cahiers d'Orientalisme 12. Genève.

1994 "Ankhtifi and the Description of his Tomb in Mo'alla," in David P. Silverman, ed., For His Ka: Essays Offered in Memory of Klaus Baer (Studies in Ancient Oriental Civilization 55; Chicago), 79-86.

Doron, Edit

1988 "On the Complementarity of Subject and Subject-Verb Agreement," in Michael Barlow and Charles A. Ferguson, ed., Agreement in Natural Language: Approaches, Theories, Descriptions: Papers Presented at a Conference held at Stanford University in October 1984 (Stanford), 201-18.

1999 "V-Movement and VP Ellipsis," in Shalom Lappin and Elabbas Benmamoun, ed., Fragments: Studies in Ellipsis and Gapping (Oxford), 124-40.

Doron, Edit, and Caroline Heycock

2010 "In Support of Broad Subjects in Hebrew," Lingua 120, 1764-76.

Drioton, Étienne

1943 "Description sommaire des chapelles funéraires de la VIe dynastie récemment découvertes derrrière le mastaba de Mérérouka à Sakkarah," Annales du Service des Antiquités de l'Égypte 43, 487-513.

Drioton, Étienne, and Jean-Philippe Lauer

1958 "Un groupe de tombes à Saqqarah: Icheti, Nefer-khouou-Ptah, Sébek-em-khent et Ankhi," Annales du Service des Antiquités de l'Égypte 55, 207-51.

Dryer, Matthew S.

2013 "Position of Tense-Aspect Affixes," in Mathew S. Dryer and Martin Haspelmath, ed., The World Atlas of Language Structures Online (Leipzig), http://wals.info/chapter/69 (accessed 05/09/2014).

Dubinsky, Stanley, and Silvester R. Simango

1996 "Passive and Stative in Chicheŵa: Evidence for Modular Distinctions in Grammar," Language 72, 74981.

Dunham, Dows

1937 The Naga-ed-Dêr Stelae of the First Intermediate Period. London.

DZA See TLA

Edel, Elmar

1955-64 Altägyptische Grammatik. Analecta Orientalia 34/39. Roma.

1959 "Beiträge zur ägyptischen Grammatik," Zeitschrift für ägyptische Sprache und Altertumskunde 84, 10513.

1973 "Unsere Kenntnis des altägyptischen," in Serge Sauneron, ed., Textee et langages de l'Égypte pharaonique: cent cinquante années de recherches 1822-1972. Hommages à Jean-François Champollion, 3 vols. (Bibliothèque d'étude 64; Cairo), I, 119-23.

1980 Neue Deutungen keilschriftlicher Umschreibungen ägyptischer Wörter und Personennamen. Sitzungsberichte der Österreichischen Akademie der Wissenschaften 375. Wien.

1981 Hieroglyphische Inschriften des Alten Reiches. Abhandlungen der Rheinisch-Westfälischen Akademie der Wissenschaften 67. Opladen.

1984a "Neue Belege für die aktivische $s \underline{d} m w$.f-Form," in Friedrich Junge, ed., Studien zu Sprache und Religion Ägyptens zu Ehren von Wolfhart Westendorf überreicht von seinen Freunden und Schülern (Göttingen), $25-39$. 
1984b Die Inschriften der Grabfronten der Siut-Gräber in Mittelägypten aus der Herakleopolitenzeit, eine Wiederherstellung nach den Zeichnungen der Description de l'Égypte. Abhandlungen der RheinischWestfälischen Akademie der Wissenschaften 71. Opladen.

1994 "Der vollständige Architrav vom Grab des $m h j$ in Saqqara," in Betsy M. Bryan and David Lorton, ed., Essays in Egyptology in Honor of Hans Goedicke (San Antonio), 61-67.

Eichler, Eckhard

1991 "Untersuchungen zu den Königsbriefen des Alten Reiches," in Studien zur altägyptischen Kultur 18, $141-71$.

el-Aguizy, Ola

2010 “Une nouvelle 'tombe-sarcophage à puits' à Saqqara," Bulletin de l'Institut Français d'Archéologie Orientale 110, 13-34.

el-Awady, Tarek

2009 Abusir, XVI. Sahure - the Pyramid Causeway: History and Decoration Program in the Old Kingdom. Prague.

el-Hamrawi, Mahmoud

2004a "Alte-Reichs-Sprache und Mittlere-Reichs-Sprache in abydenischen Texten der 11.-12. Dynastie," Lingua Aegyptia 12, 89-122.

2004b "Subtantiv + is im Altägyptichen," in Jean-Claude Goyon and Christine Cardin, ed., Proceedings of the Ninth International Congress of Egyptologists: Grenoble, 6-12 septembre 2004 (Orientalia Lovaniensia Analecta 150; Leuven), I, 545-65.

el-Khouli, Ali, and Naguib Kanawati

1988 Excavations at Saqqara, North-West of Teti’s Pyramid II. Sydney.

Elliott, Jennifer R.

2000 "Realis and Irrealis: Forms and Concepts of the Grammaticalisation of Reality," Linguistic Typology 4, 55-90.

Embick, David

2004 "On the Structure of Resultative Participles in English,” Linguistic Inquiry 35, 355-92.

Emonds, Joseph

1978 "The verbal complex V'-V in French,” Linguistic Inquiry 9, 151-75.

Englund, Gertie, und Paul John Frandsen

1986 ed., Crossroad: Chaos or the Beginning of a New Paradigm. Papers from the Conference on Egyptian Grammar. Helsingør 28-30 May 1986. Copenhagen.

Engsheden, Åke

2003 La reconstitution du verbe en égyptien de tradition 400-30 avant J.-C. Uppsala Studies in Egyptology 3. Uppsala.

Erman, Adolf

1889 Die Sprache des Papyrus Westcar. Mittheilungen der Königlichen Gesellschaft der Wissenschaften zu Göttingen. Göttingen.

1894 Ägyptische Grammatik mit Schrifttafel, Litteratur, Lesestücken und Wörterverzeichnis, 1st ed. Porta Linguarum Orientalium 15. Berlin.

1919 Reden, Rufe und Lieder auf Gräberbildern des alten Reiches. Abhandlungen der Preussischen Akademie der Wissenschaften, Philosophisch-historische Klasse 15. Berlin.

1928 Ägyptische Grammatik, mit Schrifttafel, Paradigmen und Übungstücken zum Selbststudium und zum Gebrauch in Vorlesungen. Porta Linguarum Orientalium 15. Berlin.

Eyre, Christopher J.

2013 The Use of Documents in Pharaonic Egypt. Oxford Studies in Ancient Documents. Oxford. 
Fălăuş, Anamaria

2013 "Introduction: Alternatives in Semantics and Pragmatics," in Anamaria Fălăuş, ed., Alternatives in Semantics (Palgrave Studies in Pragmatics, Language and Cognition; Basingstoke), 1-35.

Farout, Dominique

2012 “Les déclarations du roi Sahourê," Revue d'Égyptologie 63, 103-14.

2013 “Naissance du dialogue de cour sur les monuments d'Ancien Empire,” Revue d'Égyptologie 64, 15-23.

Faulkner, Raymond O.

1969 The Ancient Egyptian Pyramid Texts Translated into English, 2 vols. Oxford.

1973-78 The Ancient Egyptian Coffin Texts, 3 vols. Warminster.

1976 "The Enclitic Negation w," Journal of Egyptian Archaeology 62, 176.

1982 “A Coffin Text Miscellany,” Journal of Egyptian Archaeology 68, 27-30.

Fecht, Gerhard

1960 Wortakzent und Silbenstruktur. Untersuchungen zur Geschichte der ägyptischen Sprache. Ägyptologische Forschungen 21. Glückstadt-Hamburg-New York.

Firchow, Otto

1954 “Zu den Wortverbindungen mit ś.t," Zeitschrift für Ägyptische Sprache und Altertumskunde 79, 91-94. Fischer, Henry G.

1977 Egyptian Studies II. The Orientation of Hieroglyphs, Part 1: Reversals. New York.

1991 "Marginalia," Göttinger Miszellen 122, 12-30.

1996 Egyptian Studies III: Varia Nova. New York.

Fischer-Elfert, Hans-Werner, and Alfred Grimm

2003 “Autobiographie und Apotheose: Die Statue des Ž́( $(\check{S}) n$ Z3-Hw.t-Hrw im Staatlichen Museum Ägyptischer Kunst München," Zeitschrift für Ägyptische Sprache und Altertumskunde 130, 60-80.

Fowler Richard B. Parkinson, "The Discourse of the Fowler: Papyrus Butler verso (P. BM EA 10274)," Journal of Egyptian Archaeology 90 (2004), 81-111.

François, Alexandre

2008 "Semantic Maps and the Typology of Colexification: Intertwining Polysemous Networks across Languages," in Martine Vanhove, ed., From Polysemy to Semantic Change: Towards a Typology of Lexical Semantic Associations (Amsterdam), 163-215.

Freed, Rita E.

1996 "Stela Workshops of Early Dynasty 12," in Peter Der Manuelian, ed., Studies in Honor of William Kelly Simpson (2 vols.; Boston), I, 297-336.

Frood, Elizabeth

2007 Biographical texts from Ramessid Egypt. Writings from the Ancient World 26. Atlanta, 2007.

Fukui, Naoki

1993 "Parameters and Optionality," Linguistic Inquiry 24, 399-420.

Fukui, Naoki, and Margaret Speas

1986 "Specifiers and Projection," in Naoki Fukui et al., ed., Papers in Theoretical Linguistics (MIT Working Papers in Linguistics 8; Cambridge, MA), 128-72.

Gardiner, Alan H.

1909 The Admonitions of an Egyptian Sage from a Hieratic Papyrus in Leiden (Pap. Leiden 344 Recto). Leipzig.

1927 Egyptian Grammar. Being an Introduction to the Study of Hieroglyphs. Oxford.

1930 “A New Letter to the Dead," Journal of Egyptian Archaeology 16, 19-22.

1932 The Theory of Speach and Language. Oxford.

1935 Hieratic Papyri in the British Museum, Third Series, Chester Beatty Gift, 2 vols. London. 
1947a Ancient Egyptian Onomastica, 3 vols. Oxford.

1947b Review of Études de syntaxe copte by H. J. Polotsky, Journal of Egyptian Archaeology 33, 95-101.

1948 "The First Two Pages of the 'Wörterbuch'," Journal of Egyptian Archaeology 34, 12-18.

1950 Egyptian Grammar. Being an Introduction to the Study of Hieroglyphs. 2nd ed. Oxford.

1957 Egyptian Grammar. Being an Introduction to the Study of Hieroglyphs. 3rd ed. Oxford.

1962 My Working Years. Private printing.

Gardiner, Alan H., and Kurt Sethe

1928 Egyptian Letters to the Dead, Mainly from the Old and Middle Kingdoms. London.

Gemnikai Friedrich Wilhelm von Bissing, Die Mastaba des Gem-ni-kai, 2 vols. Berlin.

Gestermann, Louise

1994 “Neue' Texte in spätzeitlichen Grabenanlagen von Saqqara und Heliopolis,” in Martina Minas and Jürgen Zeidler, ed., Aspekte spätägyptischen Kultur: Festschrift für Erich Winter zum 65. Geburtstag (Aegyptiaca Treverensia 7; Mainz), 89-95.

Gilula, Mordechai

1970 Review of H. Satzinger, Die negativen Konstruktionen im Alt- und Mittelägyptischen (Münchner Ägyptologische Studien 12; Berlin, 1968), Journal of Egyptian Archaeology 56, $205-14$.

Givón, Talmy

2001 Syntax. An Introduction, 2nd ed. 2 vols. Amsterdam and Philadelphia.

Glanville, Stephen R. K.

1928 “The Letters of Aahmōse of Peniati," Journal of Egyptian Archaeology 14, 294-312.

Goddard, Cliff

2002 "The Search for the Shared Semantic Core of all Languages," in Cliff Goddard and Anna Wierzbicka, ed., Meaning and Universal Grammar - Theory and Empirical Findings (Amsterdam), I, 5-40.

Goedicke, Hans

1955 "The Egyptian Idea of Passing from Life to Death," Orientalia 24, 225-39.

1967 Königliche Dokumente aus dem alten Reich. Ägyptologische Abhandlungen 14. Wiesbaden.

1972 "The Letter to the Dead Naga ed-Deir N 3500," Journal of Egyptian Archaeology 58, 95-98.

1990 “About an Early Use of the Emphatic Possessive Expression,” Varia Aegyptiaca 6, 139-60.

Goelet, Ogden, Jr.

1986 "The Term stp-s' in the Old Kingdom and Its Later Development," Journal of the American Research Center in Egypt 23, 85-98.

Goldwasser, Orly

1999 “'Low' and 'High' Dialects in Ramesside Egyptian,” in Stefan Grunert and Ingelore Hafemann, ed., Textcorpus und Wörterbuch: Aspekte zur ägyptischen Lexicographie (Probleme der Ägyptologie 14; Leiden), 311-28.

2002 Prophets, Lovers and Giraffes: Wor(l)d Classification in Ancient Egypt. Göttinger Orientforschungen IV, 38. Wiesbaden.

Goyon, Jean-Claude

2012 Le recueil de prophylaxie contre les agressions des animaux venimeux du Musée de Brooklyn Papyrus Wilbour 47.2118.138. Studien zur spätägyptischen Religion 5. Wiesbaden 2012.

Gozzoli, Roberto E.

2006 The Writing of History in Ancient Egypt during the First Millennium BC (ca. 1070-180 BC): Trends and Perspectives. Golden House Publications: Egyptology 5. London.

Gracia Zamacona, Carlos

2008 Les verbes de mouvement dans les textes des sarcophages: étude sémantique, PhD dissertation, École Pratique des Hautes Études, Paris (unpublished). 
(Gracia Zamacona, Carlos)

2010 "Space, Time, and Abstract Relations in the Coffin Texts." Zeitschrift für Ägyptische Sprache und Altertumskunde 137, 13-26.

Grandet, Pierre

1998 Contes de l'Égypte ancienne. Paris.

Grandet, Pierre, and Bernard Mathieu

2003 Cours d'égyptien hiéroglyphique, Paris.

Grapow, Hermann

1914 "Über die Wortbildungen mit einem Präfix m- im Altägyptischen," Abhandlungen der Königlich Preußischen Akademie der Wissenschaften, Philosophisch-historische Klasse 5. Berlin.

Greenberg, Joseph H.

1963 "Some Universals of Grammar with Particular Reference to the Order of Meaningful Elements," in Joseph H. Greenberg, ed., Universals of Language (Cambridge), 73-113.

Griffith, Francis Ll.

1898 The Petrie Papyri: Hieratic Papyri from Kahun and Gurob (Principally of the Middle Kingdom), 2 vols. London.

Grossman, Eitan

to appear "Grammatical Variation and Language Change: the Case of Greek Loan-verbs in Coptic," in Jennifer Cromwell and Eitan Grossman, ed., Beyond Free Variation: Scribal Repertoires in Egypt from the Old Kingdom to the Early Islamic Period, Oxford, 14-16 September 2009.

Grossman, Eitan, and Stéphane Polis

2012 "Navigating Polyfunctionality in the Lexicon: Semantic Maps and Ancient Egyptian Lexical Semantics," in Eitan Grossman et al., ed., Lexical Semantics in Ancient Egyptian (Lingua Aegyptia Studia Monographica 9; Hamburg), 175-225.

Grossman, Eitan, Stéphane Polis, Andréas Stauder, and Jean Winand

2014 ed., On Forms and Functions: Studies in Ancient Egyptian Grammar. Lingua Aegyptia Studia Monographica 15. Hamburg.

Grossman, Eitan, Stéphane Polis, and Jean Winand

2012 ed., Lexical Semantics in Ancient Egyptian. Lingua Aegyptia Studia Monographica, 9. Hamburg.

Grunert, Stefan

2005 "Kulturelle Vergesslichkeit? Zu obsoleten Wörtern aus Texten des Alten Reiches," in Stephan J. Seidelmayer, ed., Texte und Denkmäler des ägyptischen Alten Reiches (Thesaurus Linguae Agyptiae 3; Berlin), 125-42.

2011 “Danse macabre: ein altägyptischer 'Totentanz' aus Saqqara,” Studien zur Altägyptischen Kultur 40, 113-36.

Guglielmi, Waltraud

1973 Reden, Rufe und Lieder auf altägyptischen Darstellungen der Landwirtschaft, Viehzucht, des Fisch-und Vogelfangs vom Mittleren Reich bis zur Spätzeit. Tübinger Ägyptologische Beiträge 1. Bonn.

Gundacker, Roman

2011 "On the Etymology of the Egyptian Crown Name mrsw.t: an 'Irregular' Subgroup of $m$-prefix Formations," Lingua Aegyptia 19, 37-86.

Gunn, Battiscombe

$1924 \quad$ Studies in Egyptian Syntax. Paris.

1948 "A Negative Word in Old Egyptian," Journal of Egyptian Archaeology 34, 27-30. Gyuris, Beáta

2009 "Quantificational Contrastive Topic with Verum/Falsum Focus,” Lingua 119, 625-49. 
Hafemann, Ingelore

2002 “Zum Zusammenspiel von Semantik und Syntax ägyptischer Verben,” Lingua Aegyptia 10, 151-210.

2005 "Textsorten und Textfunktion: Gebrauchstexte im monumentalen Diskurs des ägyptischen Alten Reiches," in Stephan J. Seidelmayer, ed., Texte und Denkmäler des ägyptischen Alten Reiches (Thesaurus Linguae Agyptiae 3; Berlin), 143-64.

Hale, Kenneth, and Samuel J. Keyser

1993 "On Argument Structure and the Lexical Expression of Syntactic Relations," in Kenneth Hale and Samuel J. Keyser, ed., The View from Building 20: Essays in Linguistics in Honor of Sylvain Boxberger (Current Studies in Linguistics 24; Cambridge, Massachusetts), 53-109.

Hammamat Jean Couyat and Pierre Montet. Les Inscriptions hiéroglyphiques et hiératiques du Ouâdi Hammâmât. Mémoires de l'Institut Français d'Archéologie Orientale 34. Cairo, 1912.

Hannig, Rainer

1982 “Zum mittelägyptischen Tempussystem,” Göttinger Miszellen 56, 35-52.

1986 "Der Kernbereich des mittelägyptischen Verbalsystems, I: Die Infinitivtempora," Journal of Ancient Civilizations, 1, 21-125.

1991 Pseudopartizip und $s \underline{d} m . n=f:$ Der Kernbereich des mittelägyptischen Verbalsystems 2. Hildesheimer Ägyptologische Beiträge 32. Hildesheim.

1995 Großes Handwörterbuch Ägyptisch-Deutsch, die Sprache der Pharaonen (2800-950 v. Chr.). Kulturgeschichte der Antiken Welt 64. Mainz.

2003 Hannig-Lexica, IV. Ägyptisches Wörterbuch I: Altes Reich und Erste Zwischenzeit. Kulturgeschichte der Antiken Welt 98. Mainz.

2006 Hannig-Lexica, V. Ägyptische Wörterbuch II: Mittleres Reich und Zweite Zwischenzeit, 2 vols. Kulturgeschichte der Antiken Welt 112. Mainz.

Hardy, Heather K., and Lynn Gordon

1980 "Types of Adverbial and Modal Constructions in Tolkapaya," International Journal of American Linguistics 46:3, 183-96.

Harley, Heidi, and Elizabeth Ritter

2002 "Person and Number in Pronouns: a Feature-geometric Analysis," Language 78, 482-526.

Haspelmath, Martin

1990 “The Grammaticalization of Passive Morphology,” Studies in Language 14, $25-72$.

1994 "Passive Participles across Languages," in Barbara Fox and Paul Hopper, ed., Voice: Form and Function (Typological Studies in Language 27; Amsterdam and Philadelphia), 151-77.

1997 Indefinite Pronouns. Oxford Studies in Typology and Linguistic Theory. Oxford.

2003 "The Geometry of Grammatical Meaning: Semantic Maps and Cross-Linguistic Comparison," in Michael Tomasello, ed., The New Psychology of Language (Mahwah, NJ), II, 211-42.

2006 “Against Markedness (and What to Replace It with)," Journal of Linguistics 42:1, 25-70.

Hassan, Selim

1936 Excavations at Gîza 1930-1931. Cairo.

1975 Excavations at Saqqara 1937-1938, ed. by Zaky Iskander. 3 vols. Cairo.

Hatnub Rudolf Anthes, Die Felsinschriften von Hatnub. Untersuchungen zur Geschichte und Altertumskunde Ägyptens 9. Leipzig, 1928.

Haviland, Susan E., and Herbert H. Clark

1974 “What's New? Acquiring New Information as a Process in Comprehension,” Journal of Verbal Learning and Verbal Behavior 13, 512-21. 
Hays, Harold M.

2012 The Organization of the Pyramid Texts, Typology and Disposition, 2 vols. Probleme der Ägyptologie 31. Leiden and Boston.

Hb. See Werning 2011, II.

Helck, Wolfgang

1972 “Zur Frage der Entstehung der ägyptischen Literatur,” Wiener Zeitschrift für die Kunde des Morgenlandes 63/64, 6-26.

1975 Historisch-biographische Texte der 2. Zwischenzeit und neue Texte der 18. Dynastie. Kleine Ägyptische Texte 6. Wiesbaden.

Heqanakht See Allen 2002.

Höhle, Tilman N

1992 “Über Verum-Fokus im Deutschen," in Joachim Jacobs, ed., Informationsstruktur und Grammatik (Linguistische Berichte Sonderhefte 10; Wiesbaden), 112-41.

Hodge, Carleton T.

1954 “An Outline of Middle Egyptian Grammar,” Studies in Linguistics 12, 8-23.

Hoekstra, Teun

1988 “Small Clause Results,” Lingua 74, 101-39.

Holmberg, Anders, and Ian Roberts

2010 "Introduction: Parameters in Minimalist Theory," in Theresa Biberauer et al., ed., Parametric Variation: Null Subjects in Minimalist Theory (Cambridge, MA), 1-57.

Hopper, Paul, and Sandra Thompson

1980 “Transitivity in Grammar and Discourse," Language 56, 251-99.

Horn, Laurence R.

2001 A Natural History of Negation. The David Hume Series: Philosophy and Cognitive Science Reissues. Stanford (originally published 1989).

Huang, Yan

2007 Pragmatics. Oxford Textbooks in Linguistics. Oxford.

Ipuwer Roland Enmarch, The Dialogue of Ipuwer and the Lord of All. Griffith Institute Publications. Oxford, 2005.

Israel, Michael

2011 The Grammar of Polarity: Pragmatics, Sensitivity, and the Logic of Scales. Cambridge Studies in Linguistics 127. Cambridge.

Jaeggli, Osvaldo A., and Kenneth J. Safir

1989 "The Null Subject Parameter and Parametric Theory,” in Osvaldo A. Jaeggli and Kenneth J. Safir, ed., The Null Subject Parameter (Studies in Natural Language and Linguistic Theory 15; Dordrecht), 1-44.

James, T. G. H.

1962 The Hekanakhte Papers and Other Early Middle Kingdom Documents. Publications of the Metropolitan Museum of Art Egyptian Expedition 19. New York.

Jansen-Winkeln, Karl

1997 “Intensivformen und ‘verbale Pluralität’ im Ägyptischen,” Lingua Aegyptia 5, 123-36.

2004 "Sprachliche Bemerkungen zu den 'Unterweltsbüchern'," Studien zur Altägyptischen Kultur 32, $205-32$.

Jéquier, Gustave

1933 Service des Antiquités de l'Égypte, Fouilles à Saqqarah. Les pyramides des reines Neit et Apouit. Cairo.

1935 Service des Antiquités de l'Égypte, Fouilles à Saqqarah. La pyramide d'Aba. Cairo.

1936 Service des Antiquités de l'Égypte, Fouilles à Saqqarah. Le monument funéraire de Pepi II, vol. I: Le tombeau royal. Cairo. 
Jespersen, Karl

1917 Negation in English and Other Languages (Det Kgl. Danske Videnskabernes Selskab, Historiskfilologiske Meddelelser I, 5). Copenhagen.

Jucker, Andreas H.

2006 "Historical pragmatics," in Keith Brown, ed., Encyclopedia of Language and Linguistics, 2nd ed. (Oxford), 329-32.

Julien, Marit

2002 Syntactic Heads and Word Formation. Oxford Studies in Comparative Syntax. Oxford.

Junge, Friedrich

1978 Syntax der mittelägyptischen Literatursprache: Grundlagen einer Strukturtheorie. Mainz.

1979 "Der Gebrauch von jw im mittelägyptischen Satz," in Manfred Görg und Edgar Pusch, ed., Festschrift Elmar Edel, 12. März 1979 (Ägypten und Altes Testament 1; Bamberg), 263-71.

1985 "Sprache," Lexikon der Ägyptologie 5, 1176-1211.

1989 "Emphasis" and Sentential Meaning in Middle Egyptian. Göttinger Orientforschungen IV, 20. Göttingen.

Junker, Hermann

1940 Gîza IV. Die Maștaba des k’jjmnh (Kai-em-anch). Österreichische Akademie der Wissenschaften, Denkschriften der Philosophisch-historische Klasse 71, 1. Vienna and Leipzig.

1943 Gîza VI. Die Mașțabas des Nfr (Nefer), Kdfjj (Kedfi), K’ḥjf (Kaḥjef) und die westlich anschließenden Grabanlagen. Österreichische Akademie der Wissenschaften, Philosophisch-historische Klasse, Denkschriften 72, 1. Vienna.

1953 Gîza XI. Der Friedhof südlich der Cheopspyramide, Ostteil. Österreichische Akademie der Wissenschafter, Philosophisch-historische Klasse, Denkschriften 74, 2. Vienna.

Kahl, Jochem, Nicole Kloth, and Ursula Zimmermann

1995 Die Inschriften der 3. Dynastie: eine Bestandsaufnahme. Ägyptologische Abhandlungen 56.Wiesbaden.

Kammerzell, Frank

1990 "Funktion und Form: zur Opposition von Perfekt und Pseudopartizip im Alt- und Mittelägyptischen," Göttinger Miszellen 117/119, 181-202.

1991a "Personalpronomina und Personalendungen im Altägyptischen," in Daniela Mendel and Ulrike Claudi, ed., Ägypten im afro-orientalischen Kontext: Aufsätze zur Archäologie, Geschichte und Sprache eines unbegrenzten Raumes, Gedenkschrift Peter Behrens (Afrikanistische Arbeitspapiere, Sondernummer; Köln), 177-203.

1991 b “Augment, Stamm und Endung: Zur morphologischen Entwicklung der Stativkonjugation," Lingua Aegyptia 1, 165-99.

1993 "Die altägyptische Negation w: Versuch einer Annäherung," Lingua Aegyptia 3, 17-32.

1998 “Sprachkontakte und Sprachwandel im Alten Ägypten.” Habilitation thesis, Georg-August-Universität Göttingen (unpublished).

2005 "Old Egyptian and Pre-Old Egyptian: Tracing linguistic Diversity in Archaic Egypt and the Creation of the Egyptian Language," in Stephan J. Seidelmayer, ed., Texte und Denkmäler des ägyptischen Alten Reiches (Thesaurus Linguae Agyptiae 3; Berlin), 165-229.

Kanawati, Naguib

2007 Deir el-Gebrawi, II: The Southern Cliff. The Australian Centre for Egyptology: Reports 25. Oxford.

Kanawati, Naguib, and Ali Hassan

1996 The Teti Cemetery at Saqqara, I: The Tomb of Nedjet-em-pet, Ka-aper and Others. The Australian Centre for Egyptology: Reports 8. Sydney. 
(Kanawati, Naguib, and Ali Hassan)

1997 The Teti Cemetery at Saqqara, II: The Tomb of Ankhmahor. The Australian Centre for Egyptology: Reports 9. Warminster.

Kanawati, Naguib, and Mohamed A. Abdel Razeq

1999 The Teti Cemetery at Saqqara V: The Tomb of Hesi. The Australian Centre for Egyptology: Reports 13. Warminster.

Kaplony, Peter

1973 "Die altesten Texte," in Serge Sauneron, ed., Textes et langages de l'Égypte pharaonique: cent cinquante années de recherches 1822-1972. Hommages à Jean-François Champollion, 3 vols. (Bibliothèque d'étude 64; Cairo), II, 3-13.

Kay, Paul

1997 "Even," in Paul Kay, Words and the Grammar of Context (CSL Lecture Notes 40. Stanford), 49-98 (originally published 1990).

Kayne, Richard

1994 The Antisymmetry of Syntax. Linguistic Inquiry Monographs 25. Cambridge.

Kheti Wolfgang Helck, Die Lehre des Dw,-

Kiss, Katalin É.

1995 "Discourse Configurational Languages: Introduction,” in Katalin É. Kiss, ed., Discourse Configurational Languages (Oxford Studies in Comparative Syntax; Oxford), 3-27.

Klebs, Luise

1922 Material zur ägyptischen Kulturgeschichte, II. Die Reliefs und Malereien des mittleren Reiches (VII.XVII. Dynastie ca 2475-1580 v. Chr.). Abhandlungen der Heidelberger Akademie der Wissenschaften, Philosophisch-historische Klasse 3. Heidelberg.

Kloth, Nicole

2002 Die (auto-)biographischen Inschriften des ägyptischen Alten Reiches: Untersuchungen zu Phraseologie und Entwicklung. Hamburg.

Klotz, David

2010 "Two Studies on the Late Period Temples at Abydos," Bulletin de l'Institut Français d'Archéologie Orientale 110, 127-63.

2013 “The Mortuary Texts on Statue JE 38001 (K. 603),” Göttinger Miszellen 236, 43-49.

Knauf, Axel

1986 “Bemerkungen zum ägyptisch-semitischen Sprachvergleich,” Göttinger Miszellen 94, 45-58.

König, Ekkehard

1997 "Zur Bedeutung der Modalpartikeln im Deutschen, ein Neuansatz im Rahmen der Relevanztheorie," Germanistische Linguistik 136, 57-75.

Koopman, Hilda, and Dominique Sportiche

1991 “The Position of Subjects,” Lingua 85, 211-58.

Kouwenberg, N. J. C.

2010 The Akkadian Verb and Its Semitic Background. Winona Lake, IN.

Kramer, Ruth

2009 "VSO and SVO Order in Middle Egyptian," in Charles G. Häberl, ed., Afroasiatic Studies in Memory of Robert Hetzron: Proceedings of the Proceedings of the 35th Annual North American Conference on Afroasiatic Linguistics (NACAL 35; Cambridge, MA), 31-75.

Kratzer, Angelika

1996 "Severing the External Argument from Its Verb," in Johan Rooryck and Laurie Zaring, ed., Phrase Structure and the Lexicon (Studies in Natural Language and Linguistic Theory 33; Dordrecht), 109-37. 
2000 "Building Statives," in Lisa J. Conathan et al., ed., Proceedings of the 26th Annual Meeting of the Berkeley Linguistic Society (BLS 26; Berkeley), 385-99.

KRI Kenneth A. Kitchen, Ramesside Inscriptions, Historical and Biographical, 8 vols. Monumenta Hannah Sheen Dedicata 1 and 3-5 (vols. 4-8). Oxford, 1975-90.

Kruchten, Jean-Marie

1982 “Convention et innovation dans un texte royal du début de l'époque ramesside: la stèle de l'an 1 de Séthi ler découverte à Beith-Shan (Musée archéologique de Jérusalem, no. 5.884)," Annuaire de l'Institut de Philologie et d'Histoire Orientales et Slaves 26, 21-62.

1999 "From Middle to Late Egyptian," Lingua Aegyptia 6, 1-97.

Kubisch, Sabine

2008 Lebensbilder der 2. Zwischenzeit. Biographische Inschriften der 13.-17. Dynastie. Sonderschrift des Deutschen Archäologischen Instituts, Kairo 34. Berlin and New York.

Lacau, Pierre, and Henri Chevrier

1956-69 Une chapelle de Sésostris Ier à Karnak, 2 vols. Cairo.

Lambdin, Thomas O.

1958 "The Bivalence of Coptic 'Eta' and Related Problems in the Vocalization of Egyptian," Journal of Near Eastern Studies 17, 177-93.

Lambrecht, Knud

1994 Information Structure and Sentence Form: Topic, Focus, and the Mental Representations of Discourse Referents. Cambridge Studies in Linguistics 71. Cambridge.

Langacker, Ronald W.

1995 "Possession and possessive constructions," in John R. Taylor and Robert E. MacLaury, ed., Language and Cognitive Construal of the World (Trends in Linguistics: Studies and Monographs 82; Oxford), 51-79.

Lapp, Günther

1997 Catalogue of Books of the Dead in the British Museum, I. The Papyrus of Nu (BM EA 10477). London.

2004 Catalogue of the Books of the Dead in the British Museum, III. The Papyrus of Nebseni (BM EA 9900). London.

Larson, Richard K.

1988 “On the Double Object Construction,” Linguistic Inquiry 19, 335-91.

Lazard, Gilbert

1998 “De la transitivité restreinte à la transitivité généralisée,” in André Rousseau, ed., La transitivité (Paris), 55-84.

LD Richard Lepsius, Denkmaeler aus Aegypten und Aethiopien, 6 vols. Berlin, 1849-59.

Leclant, Jean

1961 Montouemhat: quatrième prophète d'Amon, Prince de la ville. Bibliothèque d'étude 35. Cairo.

1974 "Les textes des pyramides," in Serge Sauneron, ed., Textes et langages de l'Égypte pharaonique: cent cinquante années de recherches 1822-1972. Hommages à Jean-François Champollion, 3 vols. (Bibliothèque d'étude 64; Cairo), II, 37-52.

Leclant, Jean, and Catherine Berger el-Naggar

2001 ed., Les textes de la pyramide de Pépy Ier, 2 vols. Mémoires de l'Institut Français d'Archéologie Orientale 118. Cairo.

Lefebvre, Gustave

1924 Le tombeau de Pétosiris. Cairo.

LES Alan H. Gardiner, Late-Egyptian Stories. Bibliotheca Aegyptiaca 1. Brussels, 1932. 
Levin, Beth, and Malka Rappaport Hovav

1995 Unaccusativity: at the Syntax-Lexical Semantics Interface. Linguistic Inquiry Monograph 26. Cambridge, MA.

Li, Charles N. and Sandra A. Thompson

1976 "Subject and Topic: A New Typology of Language," in Charles N. Li, ed., Subject and Topic (New York), 457-89.

Lichtheim, Miriam

1973 Ancient Egyptian Literature, I: The Old and Middle Kingdoms. Berkeley, Los Angeles and London.

Lipiński, Edward

2001 Semitic Languages: Outline of a Comparative Grammar, 2nd ed. Orientalia Lovaniensa Analecta 80. Leuven.

Longacre, Robert E.

1996 The Grammar of Discourse, 2nd ed. Topics in Language and Linguistics. New York.

López, Jesús

2005 Cuentos y fabulas del Antiguo Egipto. Pliegos de Oriente 9. Mandrid and Barcelona.

Loprieno, Antonio

1980 “Osservazioni sullo sviluppo dell'articolo propositivo in egiziano e nelle lingue semitiche," Oriens Antiquus 19, 1-27.

1984 “Aspekt und Diathese im Ägyptischen,” in F. Junge, ed., Studien zu Sprache und Religion Ägyptens zu Ehren von Wolfhart Westendorf überreicht von seinen Freunden und Schülern. vol. 1: Sprache (Göttingen), 87-102.

1986 Das Verbalsystem im Ägyptischen und im Semitischen: zur Grundlegung einer Aspekttheorie. Göttinger Orientforschungen IV, 17. Wiesbaden.

1991 "Topics in Egyptian Negations," in Daniela Mendel and Ulrike Claudi, ed., Ägypten im AfroOrientalischen Kontext, Aufsätze zur Archäologie, Geschichte und Sprache eines unbegrenzten Raumes: Gedenkschrift Peter Behrens (Afrikanistische Arbeitspapiere; Cologne), 213-35.

1995 Ancient Egyptian. A Linguistic Introduction, Cambridge.

2006 “On fuzzy boundaries in Egyptian syntax," in Gerald Moers et al, ed., jn.t dr.w: Festschrift für Friedrich Junge (Göttingen), 429-41.

Luft, Ulrich

1992 Das Archiv von Illahun: Briefe I. Hieratische Papyri aus den Staatlichen Museen zu Berlin, Preußischer Kulturbesitz, I. Berlin.

Luraghi, Silvia

2000 "Synkretismus," in Geert E. Booij et al., ed., Morphologie: ein internationales Handbuch zur Flexion und Wortbildung, vol. 1 (Handbücher zur Sprach- und Kommunikationswissenschaft 17:1; Berlin and New York), 638-47.

Lutz, Henry

1927 Egyptian Tomb Steles and Offering Stones of the Museum of Anthropology and Ethnology of the University of California. University of California Publications, Egyptian Archaeology. Leipzig.

Malaise, Michel, and Jean Winand

1999 Grammaire raisonnée de l'égyptien classique. Aegyptiaca Leodiensia 6. Liège. Manassa, Colleen

2006 “The Crimes of Count Sabni Reconsidered," Zeitschrift für Ägyptische Sprache und Altertumskunde 133, 151-63. 
Manuelian, Peter Der

1986 “An Essay in Document Transmission: Nj-k3-`nh and the earliest hrjw rnpt," Journal of Near Eastern Studies 45, 1-18.

1994 Living in the Past: Studies in Archaism of the Egyptian Twenty-sixth Dynasty. London and New York, Marette, Auguste

1889 Les mastabas de l'Ancien Empire. Fragment du dernier ouvrage d'Auguste Mariette, publié d'après le manuscrit de l'auteur par Gaston Maspero. Paris.

Mathieu, Bernard

2004 "La distinction entre Textes des Pyramides et Textes des Sarcophages est-elle légitime?," in Susanne Bickel and Bernard Mathieu, ed., D'un monde à l'autre: Textes des Pyramides et Textes des Sarcophages, actes de la table ronde internationale "Textes des Pyramides versus Textes des Sarcophages," IFAO 24-26 septembre 2001 (Bibliothèque d'étude 139; Cairo), 247-62.

McCloskey, James

1991 “Clause Structure, Ellipsis and Proper Government in Irish,” Lingua 85, 259-302.

McCloskey, James, and Ken Hale

1983 “On the Syntax of Person-Number Inflection in Modern Irish,” Natural Language and Linguistic Theory 1, 487-534.

2001 "The Distribution of Subject Properties in Irish,” in William D. Davis and Stanley Dubinsky, ed., Objects and Other Subjects: Grammatical Functions, Functional Categories, and Configurationality (Studies in Natural Language and Linguistic Theory 52; Dordrecht), 157-92.

McGregor, William B., and Tamsin Wagner

2006 "The Semantics and Pragmatics of Irrealis Mood in Nyulnyulan Languages," Oceanic Linguistics 4:2, 339-79.

Mehuakhti Elmar Edel, Elmar. "Inschriften des Alten Reiches III: die Stele des Mḥw-3htj (Reisner G 2375)," Mitteilung des Instituts für Orientforschung 1 (1953), 327-33.

Mereruka Sakkarah Expedition. The Mastaba of Mereruka, 2 vols. Oriental Institute Publications 31 and 39. Chicago, 1938.

Merikare Wolfgang Helck. Die Lehre für König Merikare. 2 vols. Kleine Ägyptische Texte 7. Wiesbaden, 1977.

Mink, Gerd

1978 "Allgemeine Sprachwissenschaft und Koptologie," in Robert McL. Wilson, ed., The Future of Coptic Studies (Coptic Studies I; Leiden), 71-103.

Mithun, Marianne

1995 "On the Relativity of Irreality," in Joan L. Bybee and Suzanne Fleischman, ed., Modality in Grammar and Discourse (Typological Studies in Language 32; Amsterdam and Philadelphia), 367-88.

Monaghan, James

1996 "Gardiner, Sir Alan Henderson," in Harro Stammerjohann, ed., Lexicon Grammaticorum: Who's Who in the History of World Linguistics (Tübingen), 325-27.

Montet, Pierre

1936 Les tombeaux dits de Kasr-el-Sayad," Kêmi 6, 81-129.

MOR Eberhard Otto, Das ägyptische Mundöffnungsritual, 2 vols. Ägyptologische Abhandlungen 3. Wiesbaden, 1960 .

Morenz, Ludwig D.

1996 Beiträge zur Schriftlichkeitskultur im Mittleren Reich und in der 2. Zwischenzeit. Ägypten und Altes Testament 29. Wiesbaden.

2004 Bild-Buchstaben und symbolische Zeichen. Orbis Biblicus et Orientalis 205. Fribourg and Göttingen. 
Moret, Alexandre

1931 “La légende d'Osiris à l'époque thébaine d'après l'hymne à Osiris du Louvre," Bulletin de l'Institut Français d'Archéologie Orientale 30, 725-50.

Mostafa, Maha F.

1987 “Kom el-Koffar. Teil II: Datierung und historischen Interpretation des Textes B," Annales du Service des Antiquités de l'Égypte 71, 170-84.

Moussa, Ahmed M., and Hartwig Altenmüller

1977 Das Grab des Nianchchnum und Chnumhotep. Archäologische Veröffentlichungen, Deutsches Archäologisches Institut, Kairo 21. Mainz.

Müller, Dieter

1972 “An Early Egyptian Guide to the Hereafter," Journal of Egyptian Archaeology 58, 99-125.

Müller, Matthias

2012 Review of Borghouts, Egyptian: an Introduction, Lingua Aegyptia 20, 303-10.

Naville, Édouard

1898 The Temple of Deir el Bahari, Part III. Egypt Exploration Fund Memoir 16. London.

Nedjalkov, Vladimir

1988 ed., Typology of Resultative Constructions. Translation ed. by Bernard Comrie. Typological Studies in Language 12. Amsterdam and Philadelphia.

Nedjalkov, Vladimir P., and Sergej J. Jaxontov

1988 "The Typology of Resultative Constructions," in Vladimir P. Nedjalkov, ed., Typology of Resultative Constructions (Typological Studies in Language 12; Amsterdam and Philadelphia), 3-62.

Neferti Wolfgang Helck, Die Prophezeiung des Nfr.tj, 2nd ed. Kleine Ägyptische Texte 10. Wiesbaden, 1992.

Nyord, Rune

2010 "The Radial Structure of Some Middle Egyptian Prepositions," Zeitschrift für Ägyptische Sprache und Altertumskunde 137, 27-44.

Ockinga, Boyo, and Yahia el-Masry

1988 Two Ramesside Tombs at el Mashayikh, I: The Tomb of Anhurmose - The Outer Room. Sydney.

Oréal, Elsa

2005 "Diachronie protoégyptienne et comparaison afroasiatique: la particule $j s$ de déictique à focalisateur," in Alessandro Mengozzi, ed., Studi afroasiatici: IX incontro italiano di linguistica camitosemitica (Bergamo), 69-82.

2007 "Fracture d'actance et dynamique morphosyntaxique: le renouvellement du perfectif en Ancien égyptien," Bulletin de la Société de linguistique de Paris 102, 367-97.

2009 "Same Source, Different Outcomes: A Reassessment of the Parallel between Ancient Egyptian and Akkadian 'Stative' Conjugations,” Lingua Aegyptia 17, 183-200.

2010 "Traces of a Stative-Eventive Opposition in Ancient Egyptian: Rethinking Pseudoparticiple as Old Perfective," Zeitschrift für Ägyptische Sprache und Altertumskunde 137, 145-56.

2011 Les particules en égyptien ancien: de l'ancien égyptien à l'égyptien classique. Bibliothèque d'Étude 152. Cairo.

2012 "Discourse Markers between Grammar and Lexicon: Two Ancient Egyptian Case for (De)grammaticialization," in Eitan Grossman et al., ed., Lexical Semantics in Ancient Egyptian (Lingua Aegyptia Studia Monographica 9; Hamburg), 227-45.

Osing, Jürgen

1976a Die Nominalbildung des Ägyptischen, 2 vols. Mainz.

1976b Der spätägyptische Papyrus BM 10808. Ägyptologische Abhandlungen 33. Wiesbaden. 
1987 "Die Partizipien im Ägyptischen und in den Semitischen Sprachen,” in Jürgen Osing and Günter Dreyer, ed., Form und Mass: Beiträge zur Literatur, Sprache und Kunst des alten Ägyptens; Festschrift für Gerhard Fecht zum 65. Geburtstag am 6. Februar 1987 (Ägypten und Altes Testatement 12; Wiesbaden), 337-60.

Osing, Jürgen, et al.

1982 Denkmäler der Oase Dachla: aus dem Nachlass von Ahmed Fakhry. Archäologische Veröffentlichungen, Deutsches Archäologisches Institut, Abteilung Kairo 28. Mainz.

Palmer, Frank R.

2000 Mood and Modality, 2nd ed. Cambridge Textbooks in Linguistics. Cambridge.

Pantalacci, Laure

1998 "La documentation épistolaire du palais des gouverneurs à Balat-'Ayn Asil," Bulletin de l'Institut Français d'Archéologie Orientale 98, 303-15.

Parkinson, Richard B.

1991 Voices from Ancient Egypt. An Anthology of Middle Kingdom Writings. London.

1997 The Tale of Sinuhe and Other Ancient Egyptian Poems 1940-1640 BC. Oxford.

2002 Poetry and Culture in Middle Kingdom Egypt: a Dark Side to Perfection. London and New York.

Peas. $\quad$ Richard B. Parkinson, The Tale of the Eloquent Peasant. Oxford, 1991.

pEbers Hermann Grapow, Grundriss der Medizin der Alten Ägypter, V. Die medizinische Texte in hieroglyphischer Umschreibung autographiert. Berlin, 1958.

Perrin, Loïc-Michel

2010 "Polysemous Qualities and Universal Networks, Invariance and Diversity," Linguistic Discovery 8/1, 259-80.

Peters, Stanley, and Dag Westerståhl

2006 Quantifiers in Language and Logic. Oxford.

Petosiris Gustave Lefebvre, Le tombeau de Pétosiris. Cairo, 1924.

Petrie, William M. F.

1900 Dendereh 1898. Egypt Exploration Fund Memoir 17. London.

Peust, Carsten

1999 Egyptian Phonology, an Introduction to the Phonology of a Dead Language. Monographien zur ägyptischen Sprache 2. Göttingen.

2008 “Adjektiv und Adjektivverb im Mittelägyptischen," in Carsten Peust, ed., Miscellanea in Honorem Wolfhart Westendorf (Göttinger Miszellen, Beihefte 3; Göttingen), 58-82.

Pinker, Stephen

1989 Learnability and Cognition: the Acquisition of Argument Structure. Cambridge, MA.

Polis, Stéphane

2009 "Interaction entre modalité et subjectivité en néo-égyptien: autour de la construction $m r i ̉+j w$ circ. 'souhaiter que'," in Matthias Müller and Sami Uljas, ed., Proceedings of the Fourth International Conference on Egyptian Grammar (Crossroads IV): Basel, March 19-22, 2009 (Lingua Aegyptia 17; Göttingen), 201-19.

Pollock, Jean-Yves

1989 "Verb Movement, Universal Grammar, and the Structure of IP," Linguistic Inquiry, 20, 365-424.

Polotsky, Hans J.

1929 Zu den Inschriften der 11. Dynastie. Untersuchungen zur Geschichte und Altertumskunde Ägyptens 11. Leipzig.

1944 Études de syntaxe copte, Cairo.

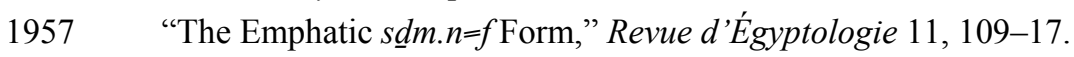


(Polotsky, Hans J.)

1965 Egyptian Tenses. The Israel Academy of Sciences and Humanities, Proceedings II 5. Jerusalem.

1976 "Les transpositions du verbe en égyptien classique," Israel Oriental Studies 6, 1-50.

Posener, Georges

1978 Catalogue des ostraca hiératiques littéraires de Deir el-Médineh, III. Documents de Fouilles 20. Cairo.

Posener-Kriéger, Paule, and Jean-Louis de Cénival

1968 Hieratic Papyri in the British Museum, V. The Abu Sir Papyri. London.

Pressl, Diana A.

1993 "Zur Königsideologie der 26. Dynastie: Untersuchungen anhand der Phraseologie der Königsinschriften," Studien zur Altägyptischen Kultur 20, 223-54.

Pries, Andreas H.

2011 Die Stundenwachen im Osiriskult, eine Studie zur Tradition und späten Rezeption von Ritualen im Alten Ägypten. Studien zur spätägyptischen Religion 2. Wiesbaden.

pSmith Hermann Grapow, Grundriss der Medizin der Alten Ägypter, V. Die medizinische Texte in hieroglyphischer Umschreibung autographiert. Berlin, 1958.

PT see Pyr.

Ptahhotep Zbyněk Žába, Les maximes de Ptahhotep. Prague, 1956.

pWestcar Aylward M. Blackman, The Story of King Kheops and the Magicians Transcribed from Papyrus Westcar (Berlin Papyrus 3033), ed. by W.V. Davies. Reading, 1988.

Pyr. $\quad$ Kurt Sethe, Die altägyptischen Pyramidentexte nach den Papierabdrücken und Photographien des Berliner Museums, 4 vols. Leipzig, 1908-22.

Quack, Joachim F.

1996 “'w 'Größe' und ` 'Zustand, Art': zwei verwechselbare demotische Wörter," Enchoria 23, 62-75.

2003 “Zum Charakter der 'zweiradikaligen’ Verben des Ägyptischen,” in M. Lionel Bender et al., ed., Selected Comparative-Historical Afrasian Linguistic Studies in Memory of Igor M. Diakonoff (LINCOM Studies in Afroasiatic Linguistics 14; Munich), 167-74.

2013 "Irrungen, Wirrungen? Forscherische Ansätze zur Datierung der älteren ägyptischen Literatur." in Gerald Moers et al., ed., Dating Egyptian Literary Texts. "Dating Egyptian Literary Texts," Göttingen, 9-12 June 2010, vol. I (Lingua Aegyptia, Studia Monographica 11; Hamburg), 405-69.

Quibell, James Edward, et al.

1898 The Ramesseum and the Tomb of Ptah-hetep. Egyptian Research Account 2. London.

Reiner, Erica

1966 A Linguistic Analysis of Akkadian. Janua Linguarum Series Practica 21. London, The Hague, and Paris. Reinhart, Tanya

1981 "Pragmatics and Linguistics: an Analysis of Sentence Topics," Philosophica 27, 53-94.

Reintges, Chris H.

1993 “A Functional Reexamination of Hammamat Inscription 191:6," in Silvio Curto et al, ed., Atti di Sesto Congresso Internazionale di Egittologia (2 vols.; Turin), II, 437-45.

1994 "Egyptian Root-and-Pattern Morphology," Lingua Aegyptia 4, 213-44.

1995 "Verbal tenses in Older Egyptian: a Reichenbachian Approach," Göttinger Miszellen 149, 83-97.

1996 "The $s \underline{d} m-t w=f$ as a Morphological Passive," Göttinger Miszellen 153, 79-99.

1997 Passive Voice in Older Egyptian: a Morpho-Syntactic Study. Holland Institute of Linguistics Dissertations 28. Den Haag.

1998 "Mapping Information Structure to Syntactic Structure: One Syntax for jn," Revue d'Égyptologie 49, $195-220$. 
2000 "The Licensing of Gaps and Resumptive Pronouns in Older Egyptian Relatives," in Jacqueline Lecarme et al., ed., Research in Afroasiatic Grammar: Papers from the Third Conference on Afroasiatic Languages, Sophia Antipolis, France 1996 (Current Issues in Linguistic Theory 202; Amsterdam and Philadelphia), 243-62.

2004a Coptic Egyptian (Sahidic Dialect): A Learner's Grammar. (Africanist Studybooks 15). Cologne.

$2004 b \quad$ "The Older Egyptian $\dot{s} \underline{d} m(. w)=f$ Passive Revisited," Folia Orientalia 40, 51-70.

2005a "The Correlation between Word Order Alternations, Grammatical Agreement and Event Semantics in Older Egyptian," in Katalin É. Kiss, ed., Universal Grammar in the Reconstruction of Ancient Languages (Studies in Generative Grammar 83; Berlin), 31-103.

2005b “On Passive Participles and Relative Forms,” Lingua Aegyptia 13, 103-39.

2006 “The Older Egyptian Stative Revisited," Lingua Aegyptia 14, 115-34.

2009 "Spontaneous Syntactic Change," in Paola Crisma and Giuseppe Longobardi, ed., Historical Syntax and Linguistic Theory (Oxford), 41-57.

2011 a "The Evolution of the Ancient Egyptian Stative: Diachronic Stability besides Inflectional Change," Folia Orientalia 48, 7-97.

$2011 \mathrm{~b} \quad$ "The Oral-Compositional Form of Pyramid Text Discourse," in Fredrik N. Hagen et al., ed., Narratives of Egypt and the Ancient Near East: Literary and Linguistic Approaches (Orientalia Lovaniensa Analecta 189; Louvain), 3-54.

2012 "Macroparametric Change and the Synthetic-Analytic Continuum: The Case of Ancient Egyptian," in Charlotte Galves et al., ed., Parameter Theory and Linguistic Change (Oxford Studies in Diachronic and Historical Linguistics 2; Oxford), 144-69.

2013 "Sapirian 'Drift' towards Analyticity and Long-term Morphosyntactic Change in Ancient Egyptian," in Ritsuko Kikusawa and Laurence A. Reid, ed., Historical Linguistics 2011: Selected Papers from the 20th International Conference on Historical Linguistics, Osaka, 25-30 July 2011 (Current Issues in Linguistic Theory 326; Amsterdam and Philadelphia), 289-328.

2015 "The Old and Early Middle Egyptian Stative: Morphosyntax • Semantics • Typology," in Eitan Grossman et al., ed., Egyptian-Coptic Linguistics in Typological Perspective (Empirical Approaches to Language Typology 55; Berlin), 387-454.

Ritter, Elisabeth

1995 "On the Syntactic Category of Pronouns and Agreement," Natural Language and Linguistic Theory 13, $405-43$.

Ritter, Thomas

1995 Das Verbalsystem der königlichen und privaten Inschriften XVIII. Dynastie bis einschließlich Amenophis III. Göttinger Orientforschungen IV, 30. Wiesbaden.

Rizzi, Luigi

1982 Issues in Italian Syntax. Studies in Generative Grammar 11. Dordrecht.

1986 "Null Objects in Italian and the Theory of Pro," Linguistic Inquiry 17, 501-57.

1997 "The Fine Structure of the Left Periphery," in Liliane Haegeman, ed., Elements of Grammar: Handbook of Generative Syntax (Kluwer International Handbooks of Linguistics 1; Dordrecht), 281-337.

Roberts, Ian G.

1993 Verbs and Diachronic Syntax: A Comparative History of English and French. Studies in Natural Languages and Linguistic Theory 28. Dordrecht.

Rothe, Russell D., William K. Miller, and George Rapp

2008 Pharaonic Inscriptions from the Southeastern Desert of Egypt. Winona Lake, IN. 
Russo, Barbara

2102 "Funerary Spells at Saqqara South: Some Considerations about the Inscriptions of Anu's Coffin (Sq20X) and Their Date," Zeitschrift für Ägyptische Sprache und Altertumskunde 139, 80-92.

Sandman, Maj

1938 Texts from the Time of Akhenaten. Bibliotheca Aegyptiaca 8. Brussels.

Satzinger, Helmut

1986 “Syntax der Präpositionsadjective ('Präpositionsnisben’)," Zeitschrift für Ägyptische Sprache und Altertumskunde 113, 141-53.

1987 "On Tense and Aspect in Middle Egyptian," in Gertie Englund and Paul J. Frandsen, ed., Crossroad: Chaos or the Beginning of a New Paradigm. Papers from the Conference on Egyptian grammar, Helsingør 28-30 May 1986 (Copenhagen), 297-313.

1988 "Towards Reconstructing the Tense System of Old Egyptian," in John D. Ray, ed., Lingua sapientissima: a Seminar in Honour of H. J. Polotsky Organised by the Fitzwilliam Museum, Cambridge and the Faculty of Oriental Studies in 1984 (Cambridge), 72-79.

1993a “'Emphase’ oder die Rhematisierung eines adverbialen Komplements im Ägyptischen,” Wiener Zeitschrift für die Kunde des Morgenlandes 83, 189-206.

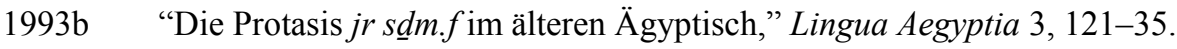

1999a "Koptische Vokalphoneme und ägyptische Pluralformation," in Stephen Emmel, ed., Ägypten und Nubien in spätantiker und christlicher Zeit: Akten des 6. Internationalen Koptologenkongresses Münster 20. - 26. Juli 1996 (Sprachen und Kulturen des christlichen Orients 6; Wiesbaden), II, 365-74.

1999b "Observations in the Field of the Afroasiatic Suffix Conjugation," in Marcello Lamberti and Livia Tonelli, ed., Afroasiatica Tergestina: Papers from the 9th Italian Meeting of Afro-Asiatic (Hamito-Semitic) Linguistics, Trieste, April 23-24, 1998 (Contributi presentati al $9^{0}$ Incontro di linguistica afroasiatica (camito-semitica), Trieste, 23-24 aprile 1998; Padova), 23-33.

2007 "Anmerkungen zu semitischen Suffixkonjugation," in Rainer M. Voigt, ed., "From beyond the Mediterranean:” Akten des 7. Internationalen Semitohamitistenkongresses (VII. ISHaK), Berlin 13. bis 15. September 2004 (Aachen), 493-500.

2012 "On Egyptian Participles and Nomina Agentis.” Folia Orientalia 49, 467-76.

2013 Review of Wolfgang Schenkel, Tübinger Einführung in die klassisch-ägyptische Sprache und Schrift (2012), Lingua Aegyptia 21, 303-309.

to appear "Semitic Suffix Conjugation and Egyptian Stative: A Hypothetic Morpho-Syntactic Scenario of its Origin" (manuscript available at http://homepage.univie.ac.at/helmut.satzinger/ Texte/Stative_Sem.pdf; accessed: 20 Jan. 2013).

Säve-Söderbergh, Torgny

1994 The Old Kingdom Cemetery at Hamra Dom (el-Qasr wa es-Saiyad). Stockholm.

Scharff, Alexander

1924 “Briefe aus Illahun,” Zeitschrift für Ägyptische Sprache und Altertumskunde 59, 20-51.

Schenkel, Wolfgang

1965a “'Singularisches’ und 'pluralisches’ Partizip,” Mitteilungen des Deutschen Archäologischen Instituts, Abteilung Kairo 20, 110-14.

1965b Memphis - Herakleopolis - Theben: die epigraphische Zeugnisse der 7.-11. Dynastie Ägyptens. Ägyptologische Abhandlungen 12. Wiesbaden.

1965c "Beiträge zur mittelägyptischen Syntax III: Sätze mit Pseudopartizip," Zeitschrift für Ägyptische Sprache und Altertumskunde 92, 47-68.

1968 "Syntagmen mit infiniten Verbalformen als Transformate von Sätzen," Mitteilungen des Deutschen Archäologischen Instituts, Abteilung Kairo 23, 167-81. 
1971 "Das altägyptische Pseudopartizip und das indogermanische Medium/Perfekt," Orientalia 40, $301-16$.

$1981 \quad$ "s $\underline{d} m=f$ und $s \underline{d} m . w=f$ als Prospektivformen," in Dwight W. Young, ed., Studies Presented to Hans Jakob Polotsky. (East Gloucester, MA), 506-17.

1983a Aus der Arbeit an einer Konkordanz zu den altägyptischen Sargtexten. Göttinger Orientforschungen IV, 12. Wiesbaden.

1983b Zur Rekonstruktion der deverbalen Nominalbildung des Ägyptischen. Göttinger Orientforschungen IV, 13. Wiesbaden.

1985 “Zur Verbalflexion der Pyramidentexte," Bibliotheca Orientalis 42, 481-94.

1990 Einführung in die altägyptische Sprachwissenschaft. Darmstadt.

1994a "śḉm.t-Perfekt und śḉm.ti-Stativ: die beiden Pseudopartizipien des Ägyptischen nach dem Zeugnis der Sargtexte," in Heike Behlmer, ed., ... quaerentes Scientiam: Festgabe für Wolfhart Westendorf zu seinem 70. Geburtstag, überreicht von seinem Schülern (Göttingen), 157-82.

1994b “Zur Formenbilding des Verbs im Neuägyptischen,” Orientalia 63, 10-15.

1996 "Eine Konkordanz zu den Sargtexten und die Graphien der 1. Person Singular," in Harco Willems, ed., The World of the Coffin Texts (Egyptologische Uitgaven 9; Leuven), 115-27.

1997 Tübinger Einführung in die klassisch-ägyptische Sprache und Schrift. Tübingen.

1998 "Standardtheorie und invertierte Standardtheorie." Zeitschrift für Ägyptische Sprache und Altertumskunde 125, 140-60.

1999 “'s-Kausativa, t-Kausativa und 'innere’ Kausativa: die ś-Kausativa der Verben I.ś in den Sargtexten," Studien zur altägyptischen Kultur 27, 313-52.

2000a "Die Endungen des Prospektivs und des Subjunktivs (śç̌m=f, śç texte," Lingua Aegyptia 7, 27-112.

2000b “Die Endungen des Negativkomplements im Spiegel der Befund der Sargtexte,” Lingua Aegyptia 7, 1-27.

2002 "Zur Formenbildung des prädikativen sč̣m=f der Verben II.gem., vornehmlich nach dem Zeugnis der Sargtexte," Göttinger Miszellen 189, 89-98.

2004 "Das śḉm(.w)=f-Passiv, Perfekt vs. Futur, nach dem Zeugnis der Sargtexte, 1. Teil," Zeitschrift für Ägyptische Sprache und Altertumskunde 131, 173-88.

2005a "Das śçm(.w)=f-Passiv, Perfekt vs. Futur, nach dem Zeugnis der Sargtexte, 2. Teil," Zeitschrift für Ägyptische Sprache und Altertumskunde 132, 40-54.

2005b “'(Sich) fernhalten' und dergleichen in den Sargtexte,” in Heinz Felber, ed., Feinde und Aufrüher Konzept von Gegnerschaft in ägyptischen Texten besonders des Mittleren Reiches (Abhandlungen der Sächsischen Akademie der Wissenschaften zu Leipzig. Philologisch-historische Klasse 78, 5; Leipzig), $111-41$.

2005c Tübinger Einführung in die klassisch-ägyptische Sprache und Schrift, 4th ed. Tübingen.

2006 "Von der Morphologie zur Syntax und zurück," Lingua Aegyptia 14, 55-82.

2007a "Die Partikel $i w$ und die Intuition des Interpreten: Randbemerkungen zu Antonio Loprieno, 'On fuzzy boundaries in Egyptian syntax'," Lingua Aegyptia 15, 161-201.

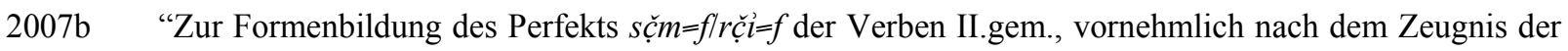
Sargtexte," Lingua Aegyptia 15, 203-16.

2008a "Substantiv / Selbständiges Personalpronomen + enklitisches Personalpronomen, eine grammatische Konstruktion des älteren Ägyptisch?,” Göttinger Miszellen 217, 97-109.

2008b "Die ägyptische Nominalbildungslehre und die Realität der hieroglyphischen Graphien der Sargtexte, II: Weitere Nominalbildungsklassen mit einer Endung -w/y/i (A II 5-10, A III 4-6 und A I 7/8/10)," Lingua Aegyptia 16, 153-70. 
(Schenkel, Wolfgang)

2009a "Predikativisches und abstrakt-relativisches sç̌m.n=f: Beobachtungen an den Verben II.gem und ult. $n$ im Korpus der Sargtexte," in Gideon Goldenberg and Ariel Shisha-Halevy, ed., Egyptian, Semitic and General Grammar: Studies in Memory of H. J. Polotsky (Jerusalem), 40-60.

2009b "Zur Silbenstruktur des Ägyptischen," Lingua Aegyptia 17, 259-76.

2010 "Die Clèresche Relativform," Zeitschrift für Ägyptische Sprache und Altertumskunde 137, 66-90.

2011 "Merkmalloses versus pluralisches/distributives/intensives Partizip: Kritik der Ausgangsbeobachtungen," Zeitschrift für Ägyptische Sprache und Altertumskunde 138, 63-78.

2012a Tübinger Einführung in die klassisch-ägyptische Sprache und Schrift, 5th ed. Tübingen.

2012b "Mittelägyptische Grammatik: Von den Texten zu den Texten," Bibliotheca Orientalis 69, 13-42.

$2012 \mathrm{c} \quad$ " $m=k+$ ini.tw=f?," Göttinger Miszellen 234, 11-13.

2014 "Syntax und Sinnzusammenhang: emphatische Konstruktion, Rang-V-Erweiterung und anderes mehr," in Harold Hays et al., ed., Interpretations of Sinuhe, Inspired by Two Passages (Proceedings of a Workshop Held at Leiden University, 27-29 November 2009) (Egyptologische Uitgaven 27; Leuven), 81-172.

im Druck "Die Farben aus der Sicht der Alten Ägypter."

Schneider, Thomas

2007 "Contextualising the Tale of the Herdsman," in Thomas Schneider and Kasia Szpakowska, ed., Egyptian Stories: a British Egyptological Tribute to A. B. Lloyd at the Occasion of his Retirement (Alter Orient und Altes Testament 347; Münster), 309-18.

Schultheiß, Alexander

2014 "Studien zur Semantik und Formenbildung der Nisbe im Älteren Ägyptischen.” PhD dissertation, Philosophische Fakultät III, Humboldt-Universität zu Berlin (unpublished).

Schweitzer, Simon D.

2000 "Untersuchungen zum Wortschatz des Papyrus Westcar und Erstellung einer Liste noch im koptischen belegter Wortformen.” Magister Artium thesis, Universität Münster (unpublished).

2005 Schrift und Sprache der 4. Dynastie. MENES 3. Wiesbaden.

Sethe, Kurt

1899 Das aegyptische Verbum im Altaegyptischen, Neuaegyptischen und Koptischen, 2 vols. Leipzig.

1923 "Die Vokalisation des Ägyptischen," Zeitschrift der Deutschen Morgenländischen Gesellschaft 77.2, 145-207.

1924 "Eine bisher unbekannte enklitische Negation im Altägyptischen," Zeitschrift für Ägyptische Sprache und Altertumskunde 59, 63-64.

1928a Dramatische Texte zu altaegyptischen Mysterienspielen. Untersuchungen zur Geschichte und Altertumskunde Ägyptens 10. Leipzig.

1928b Ägyptische Lesestücke zum Gebrauch im akademischen Unterricht. 2nd ed. Leipzig.

1936-62 Übersetzung und Kommentar zu den altägyptischen Pyramidentexten, 6 vols. Hamburg.

Sh.S. Aylward M. Blackman, "The Story of the Shipwrecked Sailor," in Aylward M. Blackman, ed., Middle Egyptian Stories (Bibliotheca Aegyptiaca 2. Brussels, 1932), 40-48.

Shisha-Halevy, Ariel

1986 "(i)rf in the Coffin Texts: a Functional Tableau," Journal of the American Oriental Society 106, 641-58. Shlonsky, Ur

1997 Clause Structure and Word Order in Hebrew and Arabic: an Essay in Comparative Semitic Syntax. Oxford Studies in Comparative Syntax 11. Oxford.

Siewierska, Anna

2004 Person. Cambridge Textbook in Linguistics. Cambridge. 
Silverman, David P.

$1980 \quad$ Interrogative Constructions with jn and jn-jw in Old and Middle Egyptian. Bibliotheca Aegyptiaca 1. Malibu.

1981 "Plural Demonstrative Constructions in Ancient Egyptian," Revue d'Égyptologie 33, 59-65.

1985 "Verbal Nominal Clauses in Middle Egyptian," in Paule Posener-Kriéger, ed., Mélanges Gamal Eddin Mokhtar, 2 vols. (Bibliothèque d'étude 47; Cairo), II, 269-85.

2000 "The Threat-Formula and Biographical Texts in the Tomb of Hezi at Saqqara," Journal of the American Research Center in Egypt 37, 1-13.

Simpson, William K.

1966 "The Letter to the Dead from the Tom of Meru (N 3737) at Nage ed-Deir," Journal of Egyptian Archaeology 52 (1966), 39-50.

1970 "A Late Old Kingdom Letter to the Dead from Nag' ed-Deir N 3500," Journal of Egyptian Archaeology $56,58-64$.

1974 The Terrace of the Great God at Abydos: the Offering Chapels of Dynasties 12 and 13. Publications of the Pennsylvania-Yale Expedition to Egypt 5. New Haven and Philadelphia.

1980 Giza Mastabas, IV. Mastabas of the Western Cemetery, Part I: Sehemka (G 1029); Tjetu I (G 2001); Iasen (G 2196); Penmeru (G 2197); Hagy, Nefertjentet, and Herunefer (G 2352/53); Djaty, Tjetu II, and Nimesti (G 2337X, 2343, 2366). Boston.

Sin. $\quad$ Roland Koch, Die Erzählung des Sinuhe. Bibliotheca Aegyptiaca 17. Brussels, 1990.

Sinai Alan H. Gardiner and T. Eric Peet, The Inscriptions of Sinai, ed. by Jaroslav Černý, 2 vols. 2nd ed. Egypt Exploration Society 45. London, 1955.

Siut $\quad$ Francis Ll. Griffith, The Inscriptions of Siût and Dêr Rîfeh. London, 1889.

Smith, Carlotta S.

1997 The Parameter of Aspect. Studies in Linguistics and Philosophy 43. Dordrecht.

Smither, Paul C.

1942 “An Old Kingdom Letter Concerning the Crimes of Count Sabni," Journal of Egyptian Archaeology 28, $16-19$.

1945 “The Semnah Dispatches," Journal of Egyptian Archaeology 31, 3-10.

Spencer, Patricia

1984 The Egyptian Temple: a Lexicographical Study. London.

Sperveslage, Gunnar

2010 “Das Kongruenzverhalten von Adjektiven im Altägyptischen,” Lingua Aegyptia 18, 217-51.

Spiegelberg, Wilhelm

1909 "Egyptian Texts," in James E. Quibell, ed., Excavations at Saqqara (1907-1908) (2 vols., Service des Antiquités de l’Égypte 5; Cairo), I, 79-83.

Stauder, Andréas

2010 "Earlier Egyptian Verbal Morphology," unpublished MS.

2013 Linguistic Dating of Middle Egyptian Literary Texts. Lingua Aegyptia Studia Monographica 12. Hamburg.

2014a The Earlier Egyptian Passive: Voice and Perspective. Lingua Aegyptia Studia Monogaphica 14. Hamburg.

2014b "Linguistic Dissonance in Sinuhe," in Harold Hays et al., ed., Interpretations of Sinuhe, Inspired by Two Passages (Proceedings of a Workshop Held at Leiden University, 27-29 November 2009) (Egyptologische Uitgaven 27; Leuven), 173-88.

2014c "Splitting the $s \underline{d} m . n=f$ ? A discussion of written forms in Coffin Texts, Part 1," Zeitschrift für Ägyptische Sprache und Altertumskunde 141, 83-96.

2014d "Splitting the $s \underline{d} m . n=f$ ? A discussion of written forms in Coffin Texts, Part 2," Zeitschrift für Ägyptische Sprache und Altertumskunde 141, 196-209. 
(Stauder, Andréas)

2014e "Interpreting written morphology: the $s \underline{d} m . n=f$ in the Pyramid Texts," Journal of Near Eastern Studies $73,253-71$.

2014f “L'émulation du passé à l'ère thoutmoside: la dimension linguistique," in Susanne Bickel, ed., Vergangenheit und Zukunft: Studien zum historischen Bewusstsein in der Thutmosidenzeit (Aegyptiaca Helvetica 22; Basel), 77-125.

Stauder-Porchet, Julie

2008 "Une formule de la biographie éthique: traduction et commentaire," Revue d'Égyptologie 58, 369-80.

2009 La préposition en égyptien de la première phase: approche sémantique. Aegyptiaca Helvetica 21. Basel.

2011 "Les autobiographies événementielles de la Ve dynastie: premier ensemble de textes continus en Égypte," in Miroslav Bárta et al., ed., Abusir and Saqqara in the Year 2010 (2 vols.; Prague), II, 747-66.

to appear Les autobiographies de l'Ancien Empire égyptien: étude sur la naissance d'un genre.

Stowell, Tim

1993 "Subject across Categories," The Linguistic Review 2, 285-312.

Strudwick, Nigel

2005 Texts from the Pyramid Age. Writings from the Ancient World 16. Atlanta.

Sybesma, Rint P. E.

2007 "Whether We Tense-agree Overtly or Not," Linguistic Inquiry 38, 580-87.

Tacke, Nikolaus

2013 Das Opferritual des ägyptischen Neuen Reiches, 2 vols. Orientalia Lovaniensia Analecta 222. Leuven, Paris and Walpole.

Tenny, Carol

1994 Aspectual Roles and the Syntax-Semantics Interface. Dordrecht.

Thacker, Thomas W.

1954 The Relationship of the Semitic and Egyptian Verbal Systems. Oxford.

Thompson, Sandra A., Robert E. Longacre, and Shin Hwang

2007 “Adverbial clauses," in Timothy Shopen, ed., Language Typology and Syntactic Description, vol. II: Complex Constructions (Cambridge), 237-300.

TLA Thesaurus Linguae Aegyptiae and Das digitalisierte Zettelarchiv(DZA), ed. by Berlin-Brandenburgische Akademie der Wissenschaften (Berlin): http://aaew2.bbaw.de/tla/.

Toivonen, Ida

2000 “The Morphosyntax of Finish Possessives,” Natural Language and Linguistic Theory 18, 579-609.

TPPI Jacques J. Clère and Jacques Vandier, Textes de la Première Période Intermédiaire et de la XIème dynastie. Bibliotheca Aegyptiaca 10. Brussels, 1948.

Uljas, Sami

2004 “Cairo Bowl Lines 7-8," Göttinger Miszellen, 201, 95-104.

2007a The Modal System of Earlier Egyptian Complement Clauses: a Study in Pragmatics in a Dead Language. Probleme der Ägyptologie 26. Leiden and Boston.

2007 " "The Earlier Egyptian Adjective Reconsidered,” Lingua Aegyptia 15, 231-50.

2008 "Methodological Remarks on Defining 'Verb Forms' in Earlier Egyptian, with Specific Reference to the $s \underline{d} m=f$ Formation," Lingua Aegyptia 16, 197-212.

2010 "Formally speaking. Observations on a Recent Theory of the Earlier Egyptian s $\underline{d m} . n=f$," Lingua Aegyptia $18,253-61$.

2011 "Syncretism and the Earlier Egyptian $s \underline{d} m=f$ : Speculations on Morphological Interconnections across Paradigms," Lingua Aegyptia 19, 155-74. 
2013 "Some Remarks on a Negated Earlier Egyptian Nominal Sentence and Related Constructions," Journal of Egyptian Archaeology 99, 241-51.

Urk.

I Kurt Sethe, Urkunden des ägyptischen Altertums, I. Urkunden des Alten Reichs. 2nd ed. Leipzig, 1933.

IV Kurt Sethe and Wolfgang Helck, Urkunden des ägyptischen Altertums, IV. Urkunden der XVIII. Dynastie. Leipzig and Berlin, 1906-1958.

VII Kurt Sethe, Urkunden des ägyptischen Altertums, VII. Historisch-biographische Urkunden des Mittleren Reiches, ed. by W. Erichsen. Leipzig, 1933.

van den Boorn, G. P. F.

1982 "On the Date of 'The Duties of the Vizier'," Orientalia 51, 369-81.

Vandekerckhove, Hans, and Renate Müller-Wollermann

2001 Elkab VI: Die Felsinschriften des Wadi Hilâl, 2 vols. Brussels.

Vandier, Jacques

1950 Mo'alla: la tombe d'Ankhtifi et la tomb de Sébekhotep. Bibliothèque d'étude 18. Cairo. van Valin, Robert D., Jr.

2006 Exploring the Syntax-Semantic Interface. Cambridge.

Varille, Alexandre

1968 Inscriptions concernant l'architecte Amenhotep fils de Hapou. Bibliothèque d'étude 44. Cairo.

Vercoutter, Jean

1958 "Une épitaphe royale inédite du Sérapéum (contribution à l'histoire des Apis et Sérapéum de Memphis)," Mitteilungen des Deutschen Archäologischen Instituts, Abteilung Kairo 16, 333-45.

Vergote, Jozef

1969 "The Plural of Nouns in Egyptian and Coptic," Orientalia 38, 77-96.

Verhagen, Arie

2005 Constructions of Intersubjectivity. Discourse, Syntax, and Cognition. Oxford.

Vernus, Pascal

1978 "Littérature et autobiographie: les inscriptions de s’-mwt surnommé Kyky," Revue d'Égyptologie 30, $115-46$.

1981 'Formes 'emphatiques' en fonction non 'emphatique' dans la protase d'un système corrélatif," Göttinger Miszellen 43, 73-88.

1984a "Sujet + s $\underline{d} m . f$ et sujet + pseudoparticipe avec les verbes de qualité: dialectique de l'aspect et de l'Aktionsart," in Friedrich Junge, ed., Studien zu Sprache und Religion Ägyptens zu Ehren von Wolfhart Westendorf, überreicht von seinen Freunden und Schülern (2 vols.; Göttingen), I, 197-212.

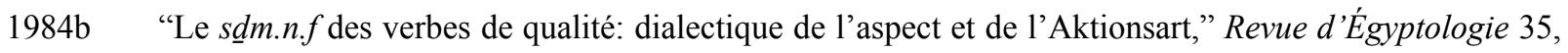
171-84.

1985 "Etudes de philologie et de linguistique IV: non-existence et définition du sujet: $b n$ prédicatif en néoégyptien," Revue d'Égyptologie 36, 153-68.

1986a “Aspect and Morphosyntactic Patterns in Middle Egyptian," in Gertie Englund and Paul Frandsen, ed., Crossroad: Chaos or the Beginning of a New Paradigm. Papers from the Conference on Egyptian Grammar, Helsingør 28-30 May 1986 (Carsten Niehbur Institute Publications 1; Copenhagen), 375-88.

1986b "Études de Philologie et de linguistique (V)," Revue d'Égyptologie 37, 141-44.

1988 “L’Egypto-copte," in Jean Perrot, ed., Les langues dans le monde ancien et moderne, troisième partie: Les langues chamito-sémitiques (Paris), 161-206.

1990a "La structure ternaire du système des déictiques dans les Textes des Sarcophages," Studi di Egittologia e di Antichità Puniche 7, 27-45. 
(Vernus, Pascal)

1990b Future at Issue. Tense, Mood and Aspect in Middle Egyptian: Studies in Syntax and Semantics. Yale Egyptological Studies 4. New Haven.

1994 "Un emploi particulier du démonstratif $n w$ dans les Textes des Sarcophages," in Catherine Berger et al., ed., Hommages à Jean Leclant (4 vols; Bibliothèque d'étude 106; Cairo), IV, 411-15.

1996a "Langue littéraire et diglossie," in Antonio Loprieno, ed., Ancient Egyptian Literature, History and Forms (Probleme der Ägyptologie 10; Leiden and New York), 555-64.

1996b "La position linguistique des Textes des Sarcophages," in Harco Willems, ed., The World of the Coffin Texts (Egyptologische Uitgaven 9; Leuven), 143-96.

1997 Les parties du discours: autopsie d'une théorie. Cahiers de la Société d'égyptologie de Genève 5. Genève.

1998 "La grammaticalisation en égyptien ancien: phrase nominale et morphogenèse de l'inaccompli et du futur," Mémoires de la Société de Linguistique de Paris 5, 63-83.

2000 "Situation de l'égyptien dans les langues du monde," in François-Xavier W. Fauvelle-Aymar et al., ed., Afrocentrisme: l'histoire des Africains entre Égypte et Amérique (Paris), 169-208.

2001 "Le nom d'action et étymologique comme modificateur du verbe: une construction égyptienne proche du maf'ül muțlaq," in Josep Cervelló Autuori and Alberto J. Quevedo Álvarez, ed., Ir a buscar leña: estudios dedicados al Prof. Jesús López (Aula Aegyptiaca Studia 2; Barcelona), 193-202.

2003 "La piété personnelle à Deir el-Médineh: la construction de l'idée de pardon," in Guillemette Andreu, ed., Deir el-Médineh et la Vallée des Rois: la vie en Egypte au temps des pharaons du Nouvel Empire. Actes du colloque organisé par le Musée du Louvre, les 3 et 4 mai 2002 (Paris), 309-47.

2004 "Le syntagme de quantification en égyptien de la première phase: sur les relations entre Textes des Pyramides et Textes des Sarcophages," in Susanne Bickel and Bernard Mathieu, ed., D'un monde à l'autre: Textes des Pyramides et Textes des Sarcophages, actes de la table ronde internationale "Textes des Pyramides versus Textes des Sarcophages," IFAO 24-26 septembre 2001 (Bibliothèque d'étude 139; Cairo), 279-311.

2006 "Pronoms interrogatifs en égyptien de la première phase," Lingua Aegyptia 14, 145-78.

2009 "Le préformant $n$ et la détransitivité Formation $n \mathrm{C}_{1} \mathrm{C}_{2} \mathrm{C}_{1} \mathrm{C}_{2}$ versus $\mathrm{C}_{1} \mathrm{C}_{2} \mathrm{C}_{1} \mathrm{C}_{2}$ : à propos de la racine $\sqrt{ } g m$ 'notion de trituration'," Lingua Aegyptia 17, 291-317

2009-10 “Comment l'élite se donne à voir dans le programme décoratif de ses chapelles funéraires: stratégie d'épure, stratégie d'appogiature et le frémissement du littéraire," in Juan C. Moreno García, ed., Élites et pouvoir en Égypte ancienne: actes du colloque Université Charles-de-Gaulle-Lille 3, 7 et 8 juillet 2006 (Cahier de Recherches de l'Institut de Papyrologie et d'Égyptologie de Lille 28; Lille), 67-116.

2010a "Du moyen égyptien au néo-égyptien, de $m$ à $m$-jr: l'auxiliation de l'impératif négatif à la dix-huitième dynastie," in Zahi Hawass and Jennifer H. Wegner, ed., Million of Jubilees: Studies in Honor of David P. Silverman (2 vols.; Annales du Service des Antiquités de l'Égypte, Supplément 39; Cairo), II, 315-35.

$2010 \mathrm{~b} \quad$ Sagesses de l'Égypte pharaonique, 2nd ed. Paris.

2010-11 “'Littérature,' 'littéraire' et supports d'écriture: contribution à une théorie de la littérature dans l'Égypte pharaonique," Egyptian and Egyptological Documents, Archives, Libraries 2, 19-145.

2012 "Le verbe $g m(j)$ : essai de sémantique lexicale," in Stéphane Polis and Jean Winand, ed., Lexical Semantics in Ancient Egyptian (Lingua Aegyptia Studia Monographica 9; Hamburg), 387-438.

2013a “The 'Royal Command' (w $\underline{d}-n s w)$ : a Basic Deed of Executive Power,” in Juan C. Moreno García, ed., Ancient Egyptian Administration (Handbuch der Orientalistik I, 104; Leiden and Boston), 259-340.

2013 b "L'acte fondamental du pouvoir dans l'Égypte pharaonique: 1' 'ordre royal' (oudj nesou)," in Silvia Bussi, ed., Egitto dai Faraoni agli Arabi: atti del convegno Egitto: amministrazione, economia, società, cultura dai faraoni agli arabi, Milano, Università degli studi, 7-9 gennaio 2013 (Pisa and Rome), 21-35. 
2013c "La datation de l'Enseignement d'Aménemopé: le littéraire et le linguistique," in Gerald Moers et al., ed., Dating Egyptian Literary Texts. "Dating Egyptian Literary Texts,” Göttingen, 9-12 June 2010, vol. I (Lingua Aegyptia Studia Monographica 11; Hamburg), 191-236.

2014 "Élaboration littéraire et affectation archaïsante: comment Sinohé sait se mettre en avant en se mettant à l'écart," in Harold M. Hays et al., ed., Interpretations of Sinuhe: Inspired by Two Passages (Proceedings of a Workshop held at Leiden University, 27-29 November 2009) (Egyptologische Uitgaven 27; Louvain), 189-213.

to appear a "Autobiographie et scènes dites 'de la vie quotidienne': de la parodie à la fiction du paysan prototypique,” in Philippe Collombert, ed., Cinquantenaire de la Mission Archéologique Française de Saqqara.

to appear b "Modelling the Relationship between Reproduction and Production of 'Sacralized' Texts in Pharaonic Egypt," in Todd Gillen, ed., Tradition and Innovation.

von Deines, Hildegard

1954 "Die Demonstrativa im Wundenbuch des Pap. Edwin Smith," Mitteilungen des Instituts für Orientforschung 2, 1-29.

Vycichl, Werner

1955 "Gab es eine Pluralendung -w im Ägyptischen?," Zeitschriften der Deutschen Morgenländischen Gesellschaft $105=$ NF 30, 261-70.

1990 La vocalisation de la langue égyptienne, I: La phonétique. Bibliothèque d'étude 16. Cairo.

Wälchli, Bernhard, and Michael Cysouw

2012 "Lexical Typology through Similarity Semantics: Toward a Semantic Map of Motion Verbs," Linguistics 50, 671-710.

Wb. $\quad$ Adolf Erman and Hermann Grapow, ed. Wörterbuch der ägyptischen Sprache im Auftrage der deutschen Akademien, 9 vols. Berlin, 1971.

Walenta, Edeltraud

1998 "Das Pseudopartizip der Sargtexte als Perfekt und Stativ." Doctoral Dissertation, University of Vienna (unpublished).

Wente, Edward F.

1975-76 “A Misplaced Letter to the Dead," Orientalia Lovaniensia Periodica 6-7, 595-600.

1990 Letters from Ancient Egypt. Writings from the Ancient World 1. Atlanta.

Werning, Daniel

2007 Table “Transkriptionssysteme wichtiger ägyptologischer Werke” in “Ägyptische Hieroglyphen,” “Wikipedia, Die freie Enzyklopädie" http://de.wikipedia.org/w/index.php?title=Ägyptische_Hieroglyphen \&oldid=33311049 (18. June 2007, 14:00 UTC; accessed: 27 Jan. 2013).

2008a "Aenigmatische Schreibungen in Unterweltsbüchern des Neuen Reiches: gesicherte Entsprechungen und Ersetzungsprinzipien," in Carsten Peust, ed., Miscellanea in honorem Wolfhart Westendorf(Göttingen), $124-52$.

2008 b “Aspect vs. Relative Tense, and the Typological Classification of the Ancient Egyptian sdm.n=f," Lingua Aegyptia 16, 261-92.

2011 Das Höhlenbuch: textkritische Edition und Textgrammatik, 2 vols. Göttinger Orientforschungen IV, 48. Wiesbaden.

2012 "Ancient Egyptian Prepositions for the Expression of Spatial Relations and Their Translations, a Typological Approach," in Eitan Grossman et al., ed., Lexical Semantics in Ancient Egyptian (Lingua Aegyptia Studia Monographica 9; Hamburg), 293-346. 
(Werning, Daniel)

2013 "Linguistic Dating of the Netherworld Books Attested in the New Kingdom," in Gerald Moers et al., ed., Dating Egyptian Literary Texts. “Dating Egyptian Literary Texts,” Göttingen, 9-12 June 2010, vol. I (Lingua Aegyptia Studia Monographica 11; Hamburg), 237-81.

2014 "Uninflected Relative Verb Forms as Converbs and Verbal Rhemes: the Two Schemes of the Emphatic Construction as a Detached Adjectival Phrase Construction and as a Truncated Balanced Sentence," in Eitan Grossman et al., ed., On Forms and Functions in Ancient Egyptian: Studies in Ancient Egyptian Grammar (Lingua Aegyptia Studia Monographica 15; Hamburg), 309-38.

Westendorf, Wolfhart

1953 "Dynamischer Gebrauch des passivisch-intransitiven Pseudopartizips," Mitteilungen des Instituts für Orientforschung 1, 38-56.

Wierzbicka, Anna

1996 Semantics. Primes and Universals. Oxford.

Wild, Henri

1953 Le tombeau de Ti, II: la chapelle (première partie). Mémoires de l'Institut français d'archéologie orientale 65, 2. Cairo.

Willems, Harco

1990 "Crime, Cult and Capital Punishment (Móalla Inscription 8)," Journal of Egyptian Archaeology 76, $27-54$.

Willis, David, Christopher Lucas, and Anne Breitbarth

2013 "Comparing Diachronies of Negation," in David Willis et al., ed., The History of Negation in the Languages of Europe and the Mediterranean, I: Case Studies (Oxford Studies in Diachronic and Historical Linguistics 5; Oxford), 1-50.

Winand, Jean

1991 “'Iy et $i w$ : unité morphologique et sémantique," Lingua Aegyptia 1, 357-88.

1992 Études de néo-égyptien 1: La morphologie verbale. Ægyptiaca Leodiensia 2. Liege.

1998 "Prolégomènes à une théorie unifiée de la temporalité en égyptien," in Christopher J. Eyre, ed., Proceedings of the Seventh International Congress of Egyptologists (Orientalia Lovaniensia Analecta 82; Leuven), 1235-45.

1999 "Un dictionnaire des verbes néo-égyptiens," in Stefan Grunert and Ingelore Hagemann, ed., Textcorpus und Wörterbuch: Aspekte zur ägyptischen Lexikographie (Probleme der Ägyptologie 14; Leiden, Boston, and Köln, 1999), 136-49.

2000 "La progression au sein de la narration en égyptien: éléments d'une grammaire du texte," Bulletin de l'Institut Français d'Archéologie Orientale 100, 403-35.

2003 "A Dictionary between Lexicon and Grammar: Interplay of Verbal Aktionsart and Grammatical Aspects," in Ingelore Hafemann, ed., Wege zu einem digitalem Corpus Ägyptischer Texte: Akten der Tagung 'Datenbanken im Verbund' (Berlin, 30. September - 2. Oktober 1999) (Thesaurus Linguae Aegyptiae 2; Berlin), $252-70$.

2004 "La non-expression de l'objet direct en égyptien ancien: études valentielles, I," Lingua Aegyptia, 12, 205-234.

2006a Temps et aspect: une approche sémantique. Probleme der Ägyptologie 25. Leiden and Boston.

2006b "A Semantic Approach to the Egyptian Language: the Case of Time and Aspect. Towards a New Paradigm," Lingua Aegyptia 14, 451-472.

2007 "Les formes nominalisées en égyptien ancien," Faits de langue 30, 69-82.

2013 Les hiéroglyphes égyptiens. Que sais-je? Paris.

2015 "Direct Object Marking (DOM) in Ancient Egyptian," in Eitan Grossman et al., ed., Egyptian-Coptic Linguistics in Typological Perspective (Empirical Approaches to Language Typology 55; Berlin), 533-60. 
Woods, Christopher

2008 The Grammar of Perspective: the Sumerian Conjugation Prefixes as a System of Voice. Cuneiform Monographs 32. Leiden and Boston.

Wright, William

1967 A Grammar of the Arabic Language, 3rd ed. Cambridge.

Wüthrich, Annik

2009 "Abracadabras méroïtiques dans le Livre des Morts?," in Burkhard Backes et al., ed., Ausgestattet mit den Schriften des Thot: Festschrift für Irmtraut Munro zu ihrem 65. Geburtstag (Studien zum Altägyptischen Totenbuch 14;Wiesbaden), 267-82.

Zakrzewska, Ewa D

1990 "Syntactic Characteristics of the Old Perfective in the Coffin Texts," Rocznik Orientalistyczny 47, $123-45$.

Zanuttini, Raffaella

1997 Negation and Clausal Structure: a Comparative Study of Romance Languages. Oxford Studies in Comparative Syntax. Oxford.

Zeidler, Jürgen

1992 Review of Karel Petráček, Vergleichende Studien, Lingua Aegyptia 2, 189-222.

1999 Pfortenbuchstudien, 2 vols. Göttinger Orientforschungen IV, 36. Wiesbaden.

Zonhoven, Louis

1996 "Studies on the $s \underline{d} m . t=f$ Verb Form in Classical Egyptian I: the Construction $\underline{d} r$ s $\underline{d}$ m.t=f," Bibliotheca Orientalis 3, 614-43.

1997a "Studies on the $s \underline{d} m . t=f$ Verb Form in Classical Egyptian II: the Active $r \underline{d} \underline{d} . t=f$ Construction," Orientalia Lovaniensia Periodica 28, 5-31.

$1997 \mathrm{~b} \quad$ "Studies on the $s \underline{d} m . t=f$ Verb Form in Classical Egyptian III: the Active $n s \underline{d m} . t=f$ Construction," in Jcabus van Dijk, ed., Essays on Ancient Egypt in Honour of Herman Te Velde (Egyptological Memoirs 1; Groeningen), 383-400. 